\title{
Are allergic multimorbidities and IgE polysensitization associated with the persistence or re-occurrence of foetal type 2 signalling? The MeDALL hypothesis
}

\author{
J. Bousquet ${ }^{1,2,3,4, *}$, J. M. Anto ${ }^{5,6,7,8}$, M. Wickman ${ }^{9,10}$,T. Keil ${ }^{11,12}$, R. Valenta ${ }^{13}$, T. Haahtela ${ }^{14}$, K. Lodrup
} Carlsen ${ }^{15,16}$, M. van Hage ${ }^{17}$, C. Akdis ${ }^{18}$, C. Bachert ${ }^{19}$, M. Akdis ${ }^{18}$, C. Auffray ${ }^{20}$, I. Annesi-Maesano ${ }^{21,22}$, C. Bindslev-Jensen ${ }^{23}$, A. Cambon-Thomsen ${ }^{24}$, K. H. Carlsen ${ }^{15,25}$, L. Chatzi ${ }^{26}$, F. Forastiere ${ }^{27}$, J. GarciaAymerich $^{5,6,7,8}$, U. Gehrig ${ }^{28}$, S. Guerra ${ }^{5}$, J. Heinrich ${ }^{29}$, G. H. Koppelman ${ }^{30}$, M. L. Kowalski ${ }^{31}$, B. Lambrecht $^{32}$, C. Lupinek ${ }^{13}$, D. Maier ${ }^{33}$, E. Melén ${ }^{10}$, I. Momas ${ }^{34,35}$, S. Palkonen ${ }^{36}$, M. Pinart ${ }^{5}$, D. Postma ${ }^{37}$, V. Siroux ${ }^{38}$, H. A. Smit ${ }^{28}$, J. Sunyer ${ }^{5,6,7,8}$, J.'Wright ${ }^{39}$, T. Zuberbier $^{40,41}$, S. H. Arshad ${ }^{42}$, R. Nadif ${ }^{3,4}{ }^{\prime}$, C. Thijs $^{43}$, N. Andersson ${ }^{9,10}$, A. Asarnoj ${ }^{9,10}$, N. Ballardini ${ }^{9}, 10$, S. Ballereau ${ }^{20}$, A. Bedbrook ${ }^{2}$, M. Benet ${ }^{\prime}{ }^{\prime}$ A. Bergstrom ${ }^{9,10}$, B. Brunekreef ${ }^{28}$, E. Burte ${ }^{3,4}$, M. Calderon ${ }^{44}$, G. De Carlo ${ }^{36}$, P. Demoly ${ }^{45}$, E. Eller $^{23}$, M. P. Fantini ${ }^{46}$, H. Hammad ${ }^{32}$, C. Hohman ${ }^{11}$ 'J. Just ${ }^{50,51}$, M. Kerkhof ${ }^{37}$, M. Kogevinas ${ }^{5,6,7,8}$, I. Kull $^{9,10}$, S. Lau ${ }^{47}$, N. Lemonnier ${ }^{20}$, M. Mommers ${ }^{43}$, M. Nawijn ${ }^{30}{ }^{\prime}$ A. Neubauer ${ }^{33}$, S. Oddie ${ }^{39}$, J. Pellet ${ }^{20}$ I. $\operatorname{Pin}^{48}$, D. Porta ${ }^{27}$, Y. Saes ${ }^{32}$, I. Skrindo ${ }^{15,16}$, C. G. Tischer ${ }^{29}$, M. Torrent ${ }^{5,49}$ \& L. von Hertzen ${ }^{14^{\prime}}$

${ }^{1}$ University Hospital, Montpellier; ${ }^{2}$ MACVIA-LR, Contre les MAladies Chroniques pour un Vleillissement Actif en Languedoc-Roussillon, European Innovation Partnership on Active and Healthy Ageing Reference Site; ${ }^{3}$ INSERM, VIMA: Ageing and Chronic Diseases Epidemiological and Public Health Approaches, U1168, Paris; ${ }^{4}$ UVSQ, UMR-S 1168, Université Versailles St-Quentin-en-Yvelines, Versailles, France; ${ }^{5}$ Centre for Research in Environmental Epidemiology (CREAL); ${ }^{6}$ Hospital del Mar Research Institute (IMIM); ${ }^{7}$ CIBER Epidemiología y Salud Pública (CIBERESP); ${ }^{8}$ Department of Experimental and Health Sciences, University of Pompeu Fabra (UPF), Barcelona, Spain; ${ }^{9}$ Sachs' Children's Hospital; ${ }^{10}$ Institute of Environmental Medicine, Karolinska Institutet, Stockholm, Sweden; ${ }^{11}$ Institute of Social Medicine, Epidemiology and Health Economics, Charité - Universitätsmedizin Berlin, Berlin; ${ }^{12}$ Institute for Clinical Epidemiology and Biometry, University of Wuerzburg, Wuerzburg, Germany; ${ }^{13}$ Division of Immunopathology, Department of Pathophysiology and Allergy Research, Center for Pathophysiology, Infectiology and Immunology, Medical University of Vienna, Vienna, Austria; ${ }^{14}$ Skin and Allergy Hospital, Helsinki University Hospital, Helsinki, Finland; ${ }^{15}$ Department of Paediatrics, Oslo University Hospital; ${ }^{16}$ Faculty of Medicine, Institute of Clinical Medicine, University of Oslo, Oslo, Norway; ${ }^{17}$ Clinical Immunology and Allergy Unit, Department of Medicine Solna, Karolinska Institutet and University Hospital, Stockholm, Sweden; ${ }^{18}$ Swiss Institute of Allergy and Asthma Research (SIAF), University of Zurich, Davos, Switzerland; ${ }^{19}$ ENT Department, Ghent University Hospital, Gent, Belgium; ${ }^{20}$ European Institute for Systems Biology and Medicine, Lyon; ${ }^{21}$ EPAR U707 INSERM, ; ${ }^{22}$ EPAR UMR-S UPMC, Paris VI, Paris, France; ${ }^{23}$ Department of Dermatology and Allergy Centre, Odense University Hospital, Odense, Denmark; ${ }^{24}$ UMR Inserm U1027, Université de Toulouse III Paul Sabatier, Toulouse, France; ${ }^{25}$ University of Oslo, Oslo, Norway; ${ }^{26}$ Department of Social Medicine, Faculty of Medicine, University of Crete, Heraklion, Crete, Greece; ${ }^{27}$ Department of Epidemiology, Regional Health Service Lazio Region, Rome, Italy; ${ }^{28}$ Julius Center of Health Sciences and Primary Care, University Medical Center Utrecht, University of Utrecht, Utrecht, the Netherlands; ${ }^{29}$ Institute of Epidemiology, German Research Centre for Environmental Health, Helmholtz Zentrum München, Neuherberg, Germany; ${ }^{30}$ Department of Pediatric Pulmonology and Pediatric Allergology, GRIAC Research Institute, University Medical Center Groningen, Beatrix Children's Hospital, University of Groningen, Groningen, the Netherlands; ${ }^{31}$ Department of Immunology, Rheumatology and Allergy, Medical University of Lodz, Lodz, Poland; ${ }^{32}$ VIB Inflammation Research Center, Ghent University, Ghent, Belgium; ${ }^{33}$ Biomay AG, Wien, Austria; ${ }^{34}$ Department of Public Health and Biostatistics, EA 4064, Paris Descartes University; ${ }^{35}$ Paris Municipal Department of Social Action, Childhood, and Health, Paris, France; ${ }^{36}$ EFA European Federation of Allergy and Airways Diseases Patients' Associations, Brussels, Belgium; ${ }^{37}$ Department of Respiratory Medicine, GRIAC Research Institute, University Medical Center Groningen, Beatrix Children's Hospital, University of Groningen, Groningen, the Netherlands; ${ }^{38}$ Inserm, U823, Grenoble, France; ${ }^{39}$ Bradford Institute for Health Research, Bradford Royal Infirmary, Bradford, UK; ${ }^{40}$ Allergy-Centre-Charité at the Department of Dermatology, Charité Universitätsmedizin Berlin; ${ }^{41}$ Secretary General of the Global Allergy and Asthma European Network (GA2LEN), Berlin, Germany; ${ }^{42}$ David Hide Asthma and Allergy Research Centre, Isle of Wight, UK; ${ }^{43}$ Department of Epidemiology, CAPHRI School of Public Health and Primary Care, Maastricht University, Maastricht, the Netherlands; ${ }^{44}$ National Heart and Lung Institute, Imperial College London, Royal Brompton Hospital NHS, London, UK; ${ }^{45}$ Department of Respiratory Diseases, Montpellier University Hospital, Montpellier, France; ${ }^{46}$ Department of Medicine and Public Health, Alma Mater Studiorum - University of Bologna, Bologna, Italy; ${ }^{47}$ Department for Pediatric Pneumology and Immunology, Charité Medical University, Berlin, Germany; ${ }^{48}$ Département de pédiatrie, CHU de Grenoble, Grenoble Cedex 9 , France; ${ }^{49}$ Area de Salut de Menorca, ib-salut, Illes Balears, Spain; ${ }^{50}$ Allergology Department, Centre de I'Asthme et des Allergies, Hôpital d'Enfants Armand-Trousseau (APHP); ${ }^{51}$ Institut Pierre Louis d'Epidémiologie et de Santé Publique, Equipe EPAR, Sorbonne Universités, UPMC Univ Paris 06, UMR_S 1136, Paris, France 
To cite this article: Bousquet J, Anto JM, Wickman M, Keil T, Valenta R, Haahtela T, Lodrup Carlsen K, van Hage M, Akdis C, Bachert C, Akdis M, Auffray C, Annesi-Maesano I, Bindslev-Jensen C, Cambon-Thomsen A, Carlsen KH, Chatzi L, Forastiere F, Garcia-Aymerich J, Gehrig U, Guerra S, Heinrich J, Koppelman GH, Kowalski ML, Lambrecht B, Lupinek C, Maier D, Melén E, Momas I, Palkonen S, Pinart M, Postma D, Siroux V, Smit HA, Sunyer J, Wright J, Zuberbier T, Arshad SH, Nadif R, Thijs C, Andersson N, Asarnoj A, Ballardini N, Ballereau S, Bedbrook A, Benet M, Bergstrom A, Brunekreef B, Burte E, Calderon M, De Carlo G, Demoly P, Eller E, Fantini MP, Hammad H, Hohman C, Just J, Kerkhof M, Kogevinas M, Kull I, Lau S, Lemonnier N, Mommers M, Nawijn M, Neubauer A, Oddie S, Pellet J, Pin I, Porta D, Saes D, Skrindo I, Tischer CG, Torrent M, von Hertzen L. Are allergic multimorbidities and IgE polysensitization associated with the persistence or re-occurrence of foetal type 2 signalling? The MeDALL hypothesis. Allergy 2015; 70: 1062-1078.

\section{Keywords}

asthma; atopic dermatitis; IgE;

polysensitization; rhinitis.

\section{Correspondence}

Jean Bousquet, CHRU Montpellier, 34295

Montpellier Cedex 5, France.

Tel.: +33611428847

Fax: +33467416701

E-mail: jean.bousquet@orange.fr

Accepted for publication 22 April 2015

DOI:10.1111/all.12637

Edited by: Thomas Bieber

\begin{abstract}
Allergic diseases [asthma, rhinitis and atopic dermatitis (AD)] are complex. They are associated with allergen-specific IgE and nonallergic mechanisms that may coexist in the same patient. In addition, these diseases tend to cluster and patients present concomitant or consecutive diseases (multimorbidity). IgE sensitization should be considered as a quantitative trait. Important clinical and immunological differences exist between mono- and polysensitized subjects. Multimorbidities of allergic diseases share common causal mechanisms that are only partly IgEmediated. Persistence of allergic diseases over time is associated with multimorbidity and/or IgE polysensitization. The importance of the family history of allergy may decrease with age. This review puts forward the hypothesis that allergic multimorbidities and $\operatorname{IgE}$ polysensitization are associated and related to the persistence or re-occurrence of foetal type 2 signalling. Asthma, rhinitis and AD are manifestations of a common systemic immune imbalance (mesodermal origin) with specific patterns of remodelling (ectodermal or endodermal origin). This study proposes a new classification of IgE-mediated allergic diseases that allows the definition of novel phenotypes to (i) better understand genetic and epigenetic mechanisms, (ii) better stratify allergic preschool children for prognosis and (iii) propose novel strategies of treatment and prevention.
\end{abstract}

IgE-mediated allergic diseases were defined by the World Allergy Organization (1) and include allergic rhinitis (2), allergic asthma (3), atopic dermatitis (AD) (4) and food allergy. However, IgE-mediated allergy is not always involved in the symptoms of these diseases (5-8) including nonallergic rhinitis, nonallergic asthma and eosinophilic esophagitis (EoE) (9-11).

In the present document, allergic diseases refer to an immune-mediated mechanism. Only IgE-associated mechanisms are considered and allergic diseases refer to IgEmediated allergic diseases.

IgE-associated allergic diseases are very complex because of the following (12):
1 IgE sensitization is characterized by the presence of allergen-specific $\operatorname{IgE}$ to environmental allergens as demonstrated by serum allergen-specific IgE or skin prick test (SPT), but not all sensitized individuals present symptoms (13).

2 Allergic and nonallergic mechanisms have been described for the same target organ and often coexist in the same patient (8).

3 Serum-specific IgE and SPT reactivities do not have the same biological and clinical relevance, and patients with dissociated tests may represent a different phenotype (14).

4 The role of family history is complex. Allergic parents usually have children with allergic diseases (15) but the majority of allergic children in the birth cohorts do not have allergic parents.

5 The definition of atopy by Coca and Cooke was proposed in 1923 (16) and included a genetic determinant. How-

\section{Abbreviations}

AD, atopic dermatitis; BAMSE, Barn (Children), Allergy, Mileu, Stockholm, Epidemiology; ECA, Environment and Childhood Asthma; ECRHS, European Community Respiratory Health Survey; EGEA, Epidemiological Study on the Genetics and Environment of Asthma, Bronchial Hyperresponsiveness and Atopy; EoE, eosinophilic enteritis; FcyRIIB, low-affinity receptor for IgG; FceRI, high-affinity receptor for IgE; GA²LEN, Global Allergy and Asthma European Network; ILC, innate lymphoid cell; MAAS, Manchester Asthma and Allergy Study; mAb, monoclonal antibody; MAS, German Multicenter Allergy Study; MeDALL, Mechanisms of the Development of ALLergy; MHC, major histocompatibility complex; SAE, Staphylococcus aureus superantigen; SPT, skin prick test; WAO, World Allergy Organization. 
ever, many components of this definition do not currently apply. The definition of atopy was modified by Pepys (17) who proposed that atopy is 'a form of immunological reactivity of the subject in which reaginic antibody, now identified as $\operatorname{IgE}$ antibody, is readily produced in response to ordinary exposure to common allergens of the subject environment'.

6 The relationship between asthma and $\operatorname{IgE}$ sensitization is not clear $(18,19)$.

7 Allergic diseases tend to cluster and patients present concomitant or consecutive diseases. The term 'comorbidity' is commonly used, but multimorbidity might be more appropriate. Comorbidity is the presence of one or more additional diseases co-occurring with a primary disease or the effect of such additional disorders or diseases. Multimorbidity is a term which means co-occurring diseases in the same patient. In most studies, the co-occurrence of a primary disease (e.g. asthma, rhinitis) has been studied and the term 'comorbidity' was correct. However, in MeDALL, we studied the cooccurrence of allergic diseases without clear information on the primary disease and the term 'multimorbidity' appears to be more appropriate except in the case of the allergic march.

$8 \mathrm{IgE}$ directed against allergens such as Staphylococcus aureus enterotoxins may play an important role (20-23).

Complex interactions of structural and inflammatory cells, cytokines, chemokines, growth factors, and mediators of inflammation and remodelling are involved in allergic diseases. It is possible that a common mechanism leads to multimorbidities and $\operatorname{IgE}$ sensitization although $\operatorname{IgE}$ sensitization does not explain the majority of multimorbidities in young children (24).

The Mechanisms of the Development of ALLergy (MeDALL) project may help to understand the links between multimorbidities and IgE polysensitization in allergic diseases using a dual approach: hypothesis driven (classical approach) and data driven (novel approach) $(12,25,26)$.

This study is based on a thorough review of the literature. It also includes the novel information found in the MeDALL studies and is therefore able to (i) assess the links between allergic multimorbidities and $\operatorname{IgE}$ sensitization as these associations have rarely been studied and (ii) propose hypotheses for a unified approach on multimorbidities and $\operatorname{IgE}$ polysensitization.

\section{From allergen-specific IgE to IgE-mediated disease}

In sensitized subjects, allergen-specific $\operatorname{IgE}$ is the initial trigger of a complex inflammatory cascade leading to symptoms and repair processes that differ between the various target organs. However, some subjects with specific IgE are asymptomatic.

\section{Basophil activation}

Basophils, mast cells and epithelial and dendritic cells represent the first cells to interact with allergens. The basophil activation test may add some information on specific $\operatorname{IgE}$ in certain allergic reactions such as cypress pollen (27), food challenges $(28,29)$ or asthma severity $(30,31)$.

\section{Allergen-specific IgE and skin tests in epidemiologic studies}

IgE sensitization can be assessed using either serum-specific IgE (32) or SPT or both, whereas in epidemiologic studies, although they show considerable overlap, they do not have the same value for the interpretation of the allergic risk $(33,34)$.

\section{Asymptomatic subjects with IgE sensitization}

Serum allergen-specific $\operatorname{IgE}$ or positive skin tests to common aeroallergens are observed in asymptomatic subjects (35-42). Using passive transfer tests, it has been shown that these antibodies are functional $(35,36)$. In the Dutch European Community Respiratory Health Survey (ECRHS) study, $43 \%$ of the subjects with IgE to inhalant allergens did not present respiratory symptoms (41). Positive skin tests in nonsymptomatic subjects precede the onset of allergic symptoms including asthma (43-48).

Asymptomatic subjects are often monosensitized (49) and have lower serum allergen-specific IgE levels than symptomatic patients for inhalant $(38,39,50)$ and food allergens (5158). Moreover, skin test reactivity to inhalant allergens is reduced in asymptomatic subjects by comparison to symptomatic patients (38).

An allergen microarray containing 103 allergen molecules has detected a high prevalence of asymptomatic IgE sensitizations to tropical pollen-derived cross-reactive carbohydrate determinants $(59,60)$. The MeDALL allergen chip contains 176 allergen molecules including seven cross-reactive carbohydrate determinants against which $\operatorname{IgE}$ are likely to be clinically irrelevant (61). The MeDALL chip has revealed that one mechanism of natural clinical tolerance to peanuts can be IgE to low allergenic peanut (62).

Allergen-specific IgE is necessary for the development of an allergic disease but many subjects have developed an IgE sensitization without symptoms.

\section{Multimorbidities of IgE-mediated allergic diseases}

\section{Multimorbidities}

Major IgE-mediated chronic diseases (rhinitis, asthma, AD) often cluster in multimorbidities. However, many unsolved problems remain:

1 The hypothesis of an atopic march suggests that AD or sometimes food allergy is the first manifestation of allergic diseases, followed by asthma and rhinitis $(63,64)$. However, this is not very common in certain populations (65).

2 Atopic dermatitis is highly prevalent in preschool children and tends to be less prevalent later in life when rhinitis 
becomes more common. However, this is not always the case $(66,67)$.

3 Atopic dermatitis is seldom present in patients with severe asthma (68), but adolescents with a severe form of AD are prone to having asthma and rhinitis (69).

4 Lung function is lower at birth among children with comorbid diseases after 10 years of age, as compared to all other children with asthma alone (70).

5 Genomewide association analysis has identified new risk genes for asthma and rhinitis comorbidity (71).

Using the 'classical' hypothesis-driven approach (24), MeDALL has discovered that, at 4 and 8 years, the coexistence of $\mathrm{AD}$, rhinitis and asthma in the same child is more common than expected by chance, both in the presence and absence of IgE sensitization. This discovery suggests that these diseases share causal mechanisms. Although IgE sensitization is independently associated with excess comorbidity of $\mathrm{AD}$, rhinitis and asthma, its presence accounted for only $38 \%$ of comorbidity. This suggests that IgE sensitization cannot be considered the dominant causal mechanism of comorbidity for these diseases at 4 and 8 years. The results of the study have been confirmed by the 'novel' data-driven approach (J. Garcia-Aymerich, submitted).

Multimorbidities of allergic diseases may share common causal mechanisms and risk factors that are only partly IgE-mediated.

\section{Importance of multimorbidities on trajectories of allergic} diseases

In one of the cohort studies from the 12 European birth cohort studies participating in MeDALL, a longitudinal analysis modelled the relation between comorbidity at 4 years of age and disease at 8 years of age (24). Children with multimorbidities at 4 years with or without IgE sensitization had higher relative risks of comorbidity at 8 years than those with a single disease. The stability was observed in the Environment and Childhood Asthma (ECA) study through puberty (66). Furthermore, in the ECA study, children with comorbid asthma, rhinitis and AD had significantly more bronchial hyperresponsiveness and signs of allergic inflammation at 16 years than children with asthma alone.

Multimorbidities of allergic diseases are associated with persistence of disease irrespective of $\operatorname{IgE}$ sensitization.

\section{Comorbid allergic diseases without IgE sensitization}

Many children and adults have symptoms resembling allergy but do not have any $\operatorname{IgE}$ sensitization. In children, asthma, rhinitis and $\mathrm{AD}$ multimorbidities prevail (24), whereas in adults, AD comorbidity appears less common. In adults, chronic rhinosinusitis may be associated with severe asthma $(72,73)$. Another disease associated with this group is EoE. This disease exists at all ages $(9,10)$ and is characterized by a Th2 eosinophilic inflammation.

Multimorbidities of allergic diseases may occur in the absence of IgE sensitization.

\section{Mono- and polysensitization against allergens}

\section{Characteristics of mono- and polysensitization}

Exposed to a common environment, the IgE-mediated immune response differs among sensitized subjects. Some react towards one or a limited number of allergens (monoor paucisensitized), whereas others are sensitized to a wide array of allergens (polysensitized) $(13,74)$ (Table 1). However, the limit between pauci- and polysensitization is still unclear.

Pepys categorized atopic status into $0,1,2$ or 3 or more groups according to the number of positive SPTs to a small battery of allergens (pollens, house dust mites, cat and a locally important mould allergen) $(17,75)$. Taking cross-reactivities between allergens and panallergens $(61,76)$ into consideration in clinical studies, a minority of symptomatic patients are monosensitized, whereas over $70 \%$ are polysensitized $(77,78)$. Similar results are found in epidemiologic studies in adults. On the other hand, polysensitization increases with age in birth cohorts $(32,79,80)$. IgE sensitization patterns differ for rhinitis and AD between 4 and 16 years. In rhinitis, the level of specific IgE increases, whereas for AD, there is an increase in polysensitization. For asthma, there is an increase in polysensitization as well as in IgE levels (32).

The discrimination between mono- and polysensitized subjects is optimally achieved using purified natural or recombinant allergens (81-87). New techniques for the determination of $\mathrm{IgE}$ reactivity profiles using microarrays improve the characterization of allergenic sensitization $(85,88)$. Different allergy patterns of PR-10 and LTP have been found according to the geographic location of the patients (89).

The characteristics of mono- and polysensitization may differ using allergen extracts or allergen components.

Table 1 Definition of polysensitization

At the extract level: IgE reactivity to several nonrelated (or not obviously related) allergenic source materials

At the molecular level: IgE reactivity to several nonrelated (or not obviously related) allergenic molecules 


\section{Allergic diseases and multimorbidities in mono- and polysensitized subjects}

In subjects with respiratory allergic symptoms, indoor allergen sensitization is strongly associated with asthma. Sensitization to pollens is mostly associated with rhinitis (90) and less with asthma (91), whereas polysensitization is more commonly associated with asthma and rhinitis comorbidity (90).

In a New Zealand cohort, in 13-year-old children, the prevalence of diagnosed asthma increased with increasing numbers of positive SPT. However, hay fever without asthma was little affected above one positive skin test (92). In a cross-sectional study, asthma was associated with polysensitization and significantly higher total IgE levels than rhinitis (93). Polysensitization was also associated with the development of asthma and its severity in the Manchester Asthma and Allergy Study (MAAS) cohort (80).

The Epidemiological Study on Genetics and Environment of Asthma, Bronchial Hyperresponsiveness and Atopy (EGEA) study examined the number of inhalant allergens assessed by SPT in subjects with rhinitis (94). The number of positive SPT was increased in subjects with asthma comorbidity (E. Burte et al., submitted).

Bronchial hyperresponsiveness to nonspecific stimuli was associated with allergen exposure (e.g. pollens) $(95,96)$ and was increased in subjects with both mite and pollen allergy, but not in those with a single allergenic sensitization (97). Increased bronchial hyperresponsiveness was also associated with asthma, rhinitis and AD comorbidity in the ECA study (66).

Rhinitis is usually associated with mono- or polysensitization, whereas asthma is more often associated with polysensitization and multimorbidities.

\section{Severity of symptoms depending on sensitization}

The impact of polysensitization on the severity of symptoms has been examined in a few studies. Nasal challenge with orchard grass induced similar symptoms and mediator release in the mono- and polysensitized subjects (98). Overall, clinical symptoms are equally severe in polysensitized and monosensitized individuals both in adults and children (77, 78, 99, 100). However, some monosensitized adults have more severe symptoms than polysensitized subjects during the ragweed or tree pollen seasons $(101,102)$.

Some allergen components (nonprevalent sensitizing allergen molecules) may be associated with symptom severity (103) and/or response to allergen immunotherapy, as suggested in children, but this requires further demonstration.

Mono- or polysensitization as an individual criterion cannot differentiate the severity of allergic symptoms.

\section{Trajectories of IgE sensitization}

Allergy in wheezing infants starts by monosensitization (104), but case histories of rapid onset of polysensitization are common (BAMSE: Barn/Children, Allergy, Milieu, Stockholm, Epidemiology). In childhood, most monosensitized subjects develop polysensitization, but there may be cases of transient sensitization later in life. In the MAS (German Multicenter Allergy Study) cohort, the IgE response against grass pollen molecules can start years before disease onset as a weak monosensitization or paucisensitization (105). The same data were found for birch pollen sensitization in the BAMSE study (106). Polysensitization, especially in early childhood, is a major risk for developing allergic diseases $(107,108)$. The number and level of $\operatorname{IgE}$ to the major PR-10 protein Bet $\mathrm{v} 1$ (major birch pollen allergen molecule) at 4 years is related to the prevalence and severity of birch pollen-related allergy at 8 and 16 years of age (106). IgE may increase in serum concentration and complexity through a 'molecular spreading' process during preclinical and early clinical disease stages (105). Parental allergy was shown to reinforce $\operatorname{IgE}$ to pollen as a preclinical biomarker of hay fever in childhood (109).

In clinical studies in adults, most monosensitized subjects with symptoms are likely not to develop new sensitizations (102, 110-113).

In young children, monosensitization is often followed by polysensitization. In adults with rhinitis, monosensitization tends to persist.

\section{IgE immune response}

Mono- and polysensitized patients differ in terms of their immune response. By comparison to polysensitized patients, monosensitized subjects usually have lower serum total $\operatorname{IgE}$ levels $(93,111,114)$ and lower serum allergenspecific IgE levels $(111,115)$. In grass pollen allergy, monosensitized patients usually react to one or two allergenic proteins of orchard grass pollen (immunoprint), whereas polysensitized patients have $\operatorname{IgE}$ against a large number of them $(98,99)$. The same was found in mite allergy for Dermatophagoides pteronyssinus (116). In MeDALL, the immunoprint data on mono- and polysensitization $(98,99)$ have been reinforced, showing that polysensitization is associated with a greater number of components for the same allergen and a higher level of IgE for each component $(106,117)$.

Clonality implies the state of a cell or a substance being derived from one source or the other. Thus, there are terms such as (i) polyclonal - derived from many clones; (ii) oligoclonal - derived from a few clones; and (iii) monoclonal derived from one clone. Although many patients are only 
sensitized to one allergen, at the clonal level, the immune response is polyclonal.

The IgE immune response differs between mono- and polysensitized patients, suggesting a dichotomy in low and high IgE responders.

Genetic associations depending on the sensitization patterns or total serum IgE levels

The immunogenetic mechanisms underlying heightened IgE responsiveness seen in allergic diseases may be divided into two types: antigen specific and nonspecific. IL-4 regulates IgE (118). Genomewide association studies have investigated groups of subjects with one or more skin tests or positive specific IgE. These studies have therefore identified genes for the non-antigen-specific response.

HLA plays a role in the development of the $\operatorname{IgE}$ response to allergens, but genetic regulation appears to differ in mono- and polysensitized patients (119). Associations between HLA haplotypes or HLA-DQ/DR molecules and allergen sensitivity were confirmed only in patients with either low total serum IgE levels or monosensitized (120124). Recent data suggest strong associations between HLA-DQ/DR variants and peanut allergy (125), but less clear associations with other food allergies such as milk or egg. In low IgE responder patients (low total $\operatorname{IgE}$ and/or monosensitized), the allergic sensitization depends more closely on HLA-DR or DQ molecules than in patients with high total IgE or polysensitized $(126,127)$. In another study, the Parietaria IgE antibody response was associated with $\mathrm{DRB} 1 * 1104$ in patients with low total $\operatorname{IgE}$ and with DRB1*1101 in patients with high total $\operatorname{IgE}(128)$. Genetic restrictions of Ole el are associated with total serum $\operatorname{IgE}$ levels (129).

The C11orf30-LRRC32 region may represent a common locus for allergic diseases through biological pathways involved in the regulation of $\operatorname{IgE}$ (130), polysensitization (131), eosinophilic inflammation (132) and comorbid allergic diseases (133) (Fig. 1).

Epigenetic associations between serum IgE concentrations and methylation at loci concentrated in $\mathrm{CpG}$ islands genomewide were studied in 95 nuclear pedigrees. Methylation at these loci differed significantly in isolated eosinophils from subjects with and without asthma and high IgE levels (134).

The different patterns of IgE and type 2 immunity associated with cosensitization between biologically unrelated allergens indicate that mono- and polysensitizations are the expression of distinct IgE-associated phenotypes. We hypothesize that they are also associated with different genetic regulation.

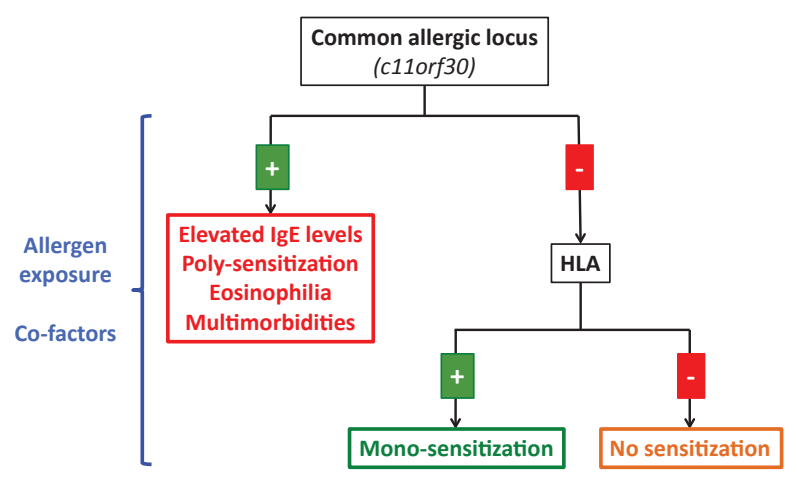

Figure 1 Differences in genetic associations between mono- and polysensitized subjects $(119,130,131,132,133)$.

\section{Developmental origin of allergic diseases}

\section{Embryologic origin of IgE comorbid diseases}

The embryologic development of the upper and lower airways begins during the fourth week of gestation and continues for many years after birth. The nose and the skin develop from the ectoderm and mesoderm, whereas the lungs develop from the endoderm and the mesoderm (135-137). The epithelial structures of the skin, that is the epidermis (surface and infundibular), apocrine units, sebaceous units, hair follicles, eccrine units and nail units, all come from ectoderm. Melanocytes, nerves and specialized sensory receptors develop from neuroectoderm (138). Other elements of the nose, lung and skin, that is inflammatory cells, fibrocytes, blood vessels, lymph vessels, muscles and adipocytes, all originate from mesoderm. The extracellular matrix (ECM) interacts with cells to regulate diverse functions, including proliferation, migration and differentiation. ECM remodelling is crucial for regulating the morphogenesis of the lung (139) (Fig. 2). We hypothesize that these morphogenetic capacities are being reused during chronic inflammatory disease with remodelling.

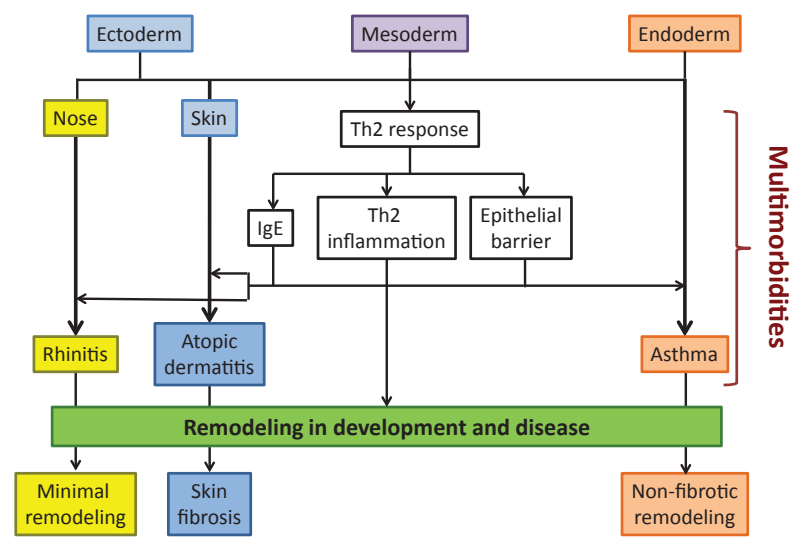

Figure 2 Embryologic origin of comorbid allergic diseases. 
The Developmental Origins of Health and Disease (DOHaD) hypothesis refers to the concept that malnutrition and other environmental factors during the foetal period induce a nature of thrift in foetuses, such that they have a higher change of developing noncommunicable diseases, such as obesity, diabetes or allergic diseases $(140,141)$. DOHaD should be viewed as part of a broad biological mechanism of plasticity by which organisms, in response to cues such as nutrition, pollution or hormones, adapt their phenotype to environment (142, 143).

Common causal mechanisms of allergic multimorbidities may be associated with foetal genes from mesoderm (Th2 signalling) or from genes regulating/interacting with ectoderm and/or endoderm $(144,145)$. On the other hand, genes regulating remodelling differ from inflammatory genes $(146,147)$ and are associated with endoderm (asthma, EoE) or ectoderm (AD, rhinitis) (Fig. 2).

We hypothesize that the common causal mechanisms of multimorbidities may be associated with the foetal genes from mesoderm. Individual diseases are likely to be associated with the foetal genes of endoderm and ectoderm.

\section{Perinatal and early life events}

Pre- and perinatal events play a fundamental role in health, in the development of diseases and in ageing (148). Allergic diseases, the most common disorders in children, begin early in life and persist across the life cycle.

The immunology of pregnancy is complex. The mother must tolerate the 'foreign' foetus requiring some immunosuppression while needing to maintain immune function to fight off infection. Successful pregnancy maintenance associates a switch from Th1 to the Th2 profile and Treg interaction $(149,150)$.

The process of immune deviation already begins in utero $(151,152)$. IgE is produced by the foetus $(153,154)$, and its level in cord blood is associated with the further development of allergic diseases in childhood. The effect may be weaning in adults $(15,155)$. The affinity of $\operatorname{IgE}$ may be low in cord blood (156). The continuation of foetal allergen-specific Th2 responses during infancy appears to be a feature of the inductive phase of allergic disease, although more data are needed to fully understand the kinetics of Th1 and Th2 cytokines in infancy (157-159). Reduced IFN- $\gamma$ and enhanced IL-4-producing $\mathrm{CD}^{+}{ }^{+}$cord blood $\mathrm{T}$ cells are associated with a higher AD risk at 2 years (160). The first 6 months of life are also critical for the development of the Th2 response and allergic diseases (161). IL-4 production at 3 months is associated with $\operatorname{IgE}$ levels at 5 years (162). Birth cohort studies are relevant for the investigation of the environmental and lifestyle determinants of asthma and IgEassociated diseases as well as the absence of such diseases $(163,164)$ (Fig. 3).
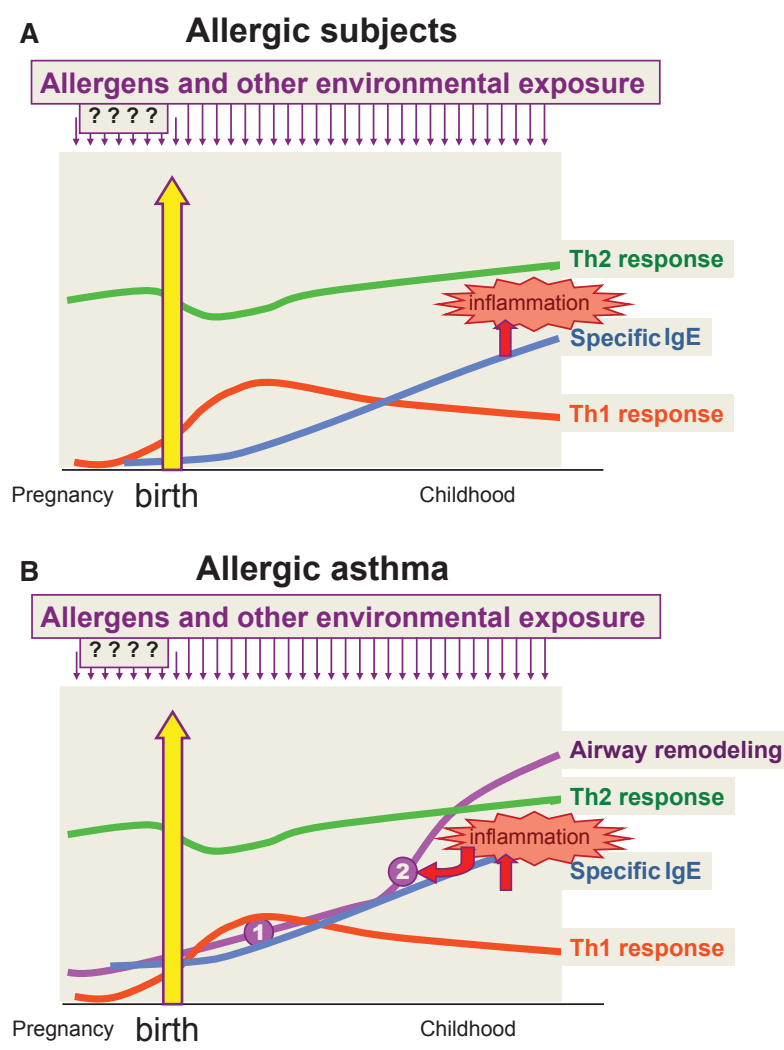

Figure 3 (A, B) Foetal gene persistence in allergic diseases and asthma [from Ref. (178)].

Several sets of genes are likely to interact with the environment for the development of allergic diseases and asthma: genes governing the IgE immune response, remodelling (165), inflammation and oxidative stress (166) as well as those involved in the epithelial barrier function $(167,168)$. Genes encoding Th2 cytokines such as IL-4 and IL-13 (169-171) or remodelling are conserved foetal genes persisting across the life cycle (171) (Fig. 3). Several asthma susceptibility genes are differentially expressed during lung development, which suggests common mechanisms underlying lung morphogenesis and pathogenesis of asthma and allergic diseases (172). Moreover, these genes interact in these diseases and multimorbidities (173). One example is the Th2 (IL-4, IL-13) involved in $\operatorname{IgE}$ production, the regulation of the epithelial barrier function in the skin (174) and the airways (175), remodelling and fibrosis (176).

The allergy epidemic may have resulted from recent environmental changes interacting with genes. Epigenetic mechanisms may help to understand the epidemics of allergic diseases and asthma, such as the important role of pre- and postnatal environmental factors that may programme an individual towards disease (177). Epigenetic phenomena may contribute to a Th1 and Th2 imbalance (178). As epigenetics mediates genomic imprinting during embryogenesis, it may 
be involved with the multigenerational transmission of allergic diseases and asthma (179).

Several sets of unsilenced foetal genes act in combination to induce an $\mathrm{IgE}$ immune inflammation, remodelling and multimorbidities. Epigenetic mechanisms are at the forefront of the development of allergic diseases.

\section{Importance of type 2 signalling in inflammation and remodelling in allergic diseases}

\section{Asthma and rhinitis}

Asthma is an inflammatory disease of the entire airways and airway wall remodelling (180-182). In response to allergen presentation by airway dendritic cells, Th cells of the adaptive immune system control many aspects of the disease through the secretion of IL-4, IL-5, IL-13, IL-17 and IL-22. These are counterbalanced by cytokines produced by Treg cells (183). IL-4, IL-13, IL-33 and thymic stromal lymphopoietin (TSLP) (184) play a key role in allergic disease by their ability to initiate, maintain and augment Th2 responses (185-187). Many innate immune system cells (mast cells, basophils, neutrophils, eosinophils and lymphoid type 2 cells ILCs) have an important role. ICLs produce IL-5 and IL-13 (188). The bronchial epithelium protects the internal milieu of the lung from noxious agents by forming a physical barrier involving adhesive complexes and a chemical barrier (189). It can release cytokines and chemokines (190-192), is a sense exposure to allergens and may result in $\operatorname{IgE}$ sensitization.

In asthma and rhinitis, the inflammation of nasal and bronchial mucosa appears to be sustained by a similar inflammatory infiltrate including eosinophils, mast cells, $\mathrm{T}$ lymphocytes and macrophages (193), as well as similar proinflammatory mediators (histamine, cysteinyl leukotrienes), Th2 cytokines and chemokines. However, there are differences between the two sites and both unique and shared genetic factors for asthma and rhinitis have been identified (194). The importance of the Th2 pathway in eosinophilic asthmatics is supported by the efficacy of a mAb against IL4/IL-13 (195).

Remodelling is present in the airways of most if not all asthmatics $(180,196)$ and is only partly associated with a Th2 inflammation (180). Remodelling exists very early in life in asthma. On the other hand, although the epithelial mesenchymal trophic unit exists in rhinitis, nasal remodelling in rhinitis seems to be far less extensive than in the bronchi of asthmatics (197). Tissue remodelling exists in rhinosinusitis (198). Epithelial barrier and remodelling features close to those of asthma are found in EoE, a Th2 often non-IgEassociated disease of an endodermic organ (9, 199-203).

Periostin, an ECM protein belonging to the fasciclin family, plays a critical role in remodelling during development or repair (204). It is a downstream molecule of IL-4 and IL-13 and a component of subepithelial fibrosis in asthma (205).
Periostin expression is minimally increased in the nasal mucosa of patients with allergic rhinitis, whereas it is highly increased in rhinosinusitis (206).

Type 2 inflammation has a central role in asthma and rhinitis. Remodelling is extensive in asthma, whereas it is less extensive in rhinitis.

\section{Atopic dermatitis}

In $\mathrm{AD}$, abnormalities in terminal differentiation of the epidermal epithelium, leading to a defective stratum corneum, allow enhanced allergen penetration and systemic IgE sensitization (207). Causes of this abnormal skin barrier are complex and driven by a combination of genetic, environmental and immunologic factors. Mutations in filaggrin (FLG), a structural protein fundamental in the development and maintenance of the skin barrier, are the best identified. However, variants associated with $\mathrm{AD}$ exist in genes encoding for other proteins involved in the skin barrier (208). FLG variants also increased risk of allergic multimorbidities, which may represent more severe and complex clinical phenotypes. Allergic sensitization and AD modulated the association between FLG variants, asthma and food allergy (209) but less with rhinitis $(210,211)$.

The pathogenesis of AD is complex and includes a Th2 deviation, a role for specialized dendritic cells as well as Th17 and Th22 cells (212). Periostin is also involved in AD $(213,214)$. Dupilumab, a mAb against IL-4/IL-13, is effective in AD. It improves molecular signature $(215,216)$ suggesting that IL-4 and IL-13 drive a complex, Th2-centred inflammatory axis in patients with AD. Skin fibrotic remodelling is a major feature in $\mathrm{AD}$, but as a consequence of skin irritation.

Atopic dermatitis is associated with a defective skin barrier function and a complex immune response in which type 2 signalling plays an important role.

\section{Integration of concepts}

\section{Type 2 comorbid phenotypes}

\section{IgE-associated phenotypes}

IgE-associated allergy with eosinophilic inflammation is a common feature of allergic asthma, allergic rhinitis, some forms of AD and allergic EoE $(217,218)$. Three extreme phenotypes appear to coexist with intermediate phenotypes and nonsensitization. These phenotypes may vary with age.

1 Nonsensitized asymptomatic individuals

2 IgE response restricted to one environmental allergen with no family history: low $\operatorname{IgE}$ responders (number of components and level of IgE) 
a Nonsymptomatic subjects who are unlikely to develop symptoms over time.

b Symptomatic subjects (symptoms similar to polysensitized subjects):

- These subjects become sensitized because there is a substantial level of allergen exposure and subsequent exposure to cofactors (e.g. traffic-related air pollutants) (219). This is the case for tree pollens (cypress, birch) or new pollens (ragweed in northern Italy) (102) and soybean outbreaks (220).

- There is usually no family history.

- In cypress pollen allergic patients, at the beginning of the disease, skin tests are not positive between seasons, only during season.

- Patients mostly suffer from rhinitis (the case of cypress and birch pollen allergy) (221).

3 Polyclonal $\mathrm{IgE}$ response to environmental allergens with family history: high IgE responders (number of components and level of $\operatorname{IgE}$ ). Most subjects are symptomatic, with an early life onset, a high rate of multimorbidities and persistence of the disease over time.

4 Nonallergic polyclonal IgE without family history: Lateonset disease and local polyclonal IgE: Some patients develop asthma late in life. In these patients, positive SPTs or serum IgE antibodies to inhalant allergens are not common, but there is often an increase in total serum IgE (222). These patients frequently suffer from comorbid upper airway disease (rhinosinusitis) (72) and more severe asthma (223). In chronic rhinosinusitis with nasal polyps (CRSwNP), significantly associated with asthma comorbidity, there is a local $\operatorname{IgE}$ production in the upper airway mucosa (224) and a strong polyclonal mucosal local IgE production (IgE antibodies to several hundred allergens) which is functional upon allergen exposure (225). Together with specific IgE to inhalant allergens, $\operatorname{IgE}$ antibodies to Staphylococcus aureus enterotoxins (SE-IgE) can be demonstrated in the mucosa. The presence of this antibody and a high increase in total IgE are significantly associated with asthma comorbidity (22). In asthmatics, serum SE-IgE correlates with total $\operatorname{IgE}$ and is associated

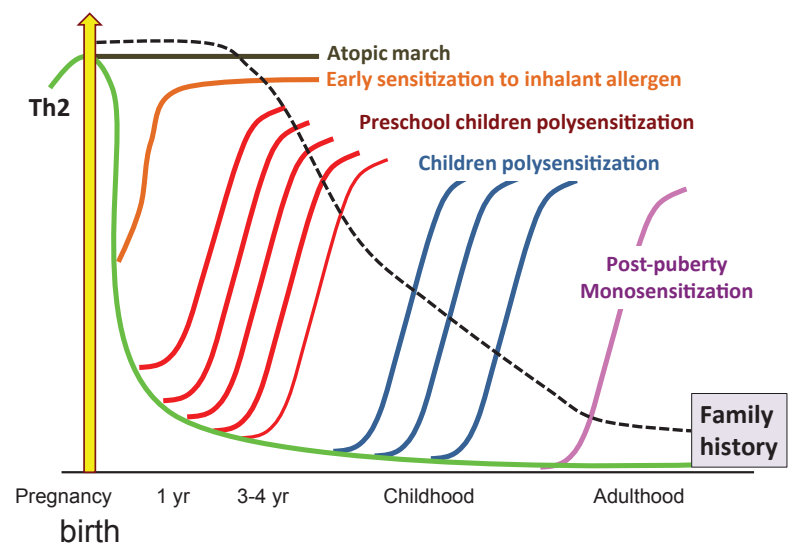

Figure 4 Phenotypes of IgE-mediated allergic diseases.
Table 2 Implications of the novel definition of IgE-mediated allergic diseases

Subphenotyping of allergic diseases: Phenotyping subtypes can be used to characterize allergic diseases, severity and progression and may help identify unique targets for prevention and treatment Clinical practice: An updated definition provides a framework to inform decisions relating to treatment priorities and to indicate need for improvement in health care and delivery through better organization for prediction, diagnosis and treatment. The prediction of allergic disease trajectories in preschool children is essential

Clinical trials: Clarity on definitions is essential for clinical trials, evaluating efficacy and safety. The stratification of patients by sensitization and comorbidity is essential in allergen immunotherapy (for both treatment and prevention)

Research on mechanisms and genetics: The new definition is likely to change the concepts of the mechanisms of allergic disease and to propose novel mechanisms

Population studies: In longitudinal epidemiological population studies, standardized definitions are required to be able to compare cohorts across time and place and to develop dynamic models capturing risk factors which predict transitions through different stages of health

Public health planning: For public health purposes, a comprehensive definition is needed (i) to identify the prevalence, burden and costs incurred by all phenotypes; (ii) to improve quality of care and optimize healthcare planning and policies; and (iii) to model the economic and social benefits of specific interventions to improve or maintain health

Social welfare planning: For social welfare purposes, a phenotypic definition is also needed to predict the burden and costs at an early age in order to model the individual and collective economic and social benefits of specific interventions

Applicability to high- and low-income countries: A uniform allergy definition should be applicable to the local and geographical conditions of all countries, phenotypes, risk factors, availability and affordability to treatment differing widely around the world. This would help to better understand mechanisms specific to different environments and interactions with parasitic diseases in particular

Development of novel preventive approaches and therapies: Detailed cellular and molecular phenotyping is needed to identify novel primary and secondary prevention strategies, as well as new targets for the development of novel therapies. Ultimately, novel therapies studied in clinical trials should help define IgEmediated pathways and determine the importance of the intervention in large patient populations or in subpopulations of patients based on the concept of distinct phenotypes. The life course approach of allergic diseases is of great interest as it may lead to health promotion strategies

with the severity of the disease $(226,227)$. A Th2 immune response has been demonstrated in the nasal polyps of these patients (22).

5 Intermediate phenotypes

a Polyclonal IgE response without family history. The role of cofactors (pollutants, viruses) needs to be better understood.

b IgE response restricted to few allergens. 


\section{Non-IgE-associated phenotypes}

Eosinophilic diseases without IgE-mediated allergy exist in both children and adults. They include asthma, rhinitis, rhinosinusitis, some forms of $\mathrm{AD}$ and nonallergic EoE.

\section{Temporal integrations of type 2 comorbid phenotypes}

Allergens and environmental cofactors [inhaled (219, 228), nutritional, bacterial and viral infections (164, 229, 230), microbiome (231-234), etc.] act at different times of pregnancy and the life cycle in subjects with a variable genetic predisposition to develop an IgE-mediated disease. Moreover, the trajectories of subjects with an IgE response vary widely. It is known that environmental factors can act in utero and may have more impact in early life rather than in later life. However, their role is still unclear.

Allergic diseases are highly heterogeneous including many different and overlapping phenotypes which may, however, be theoretically simplified in a few scenarios (Fig. 4):

1 Early-onset $\mathrm{AD}$ and subsequent comorbidities included in the atopic march. A few children follow the typical atopic march pattern (65), and in these subjects, it may be considered that foetal life type 2 signalling persists throughout life from birth (235).

In the other groups, type 2 signalling re-occurs in response to allergen and the effect of cofactors, increasing with age. The importance of the family history of allergy decreases with age, but genetic factors cannot be ruled out even in subjects developing allergy in adulthood.

2 Early development of sensitization to an inhalant allergen present in very high amounts in early life. Neonatal birch pollen exposure can induce the development of birch pollen allergy in some (236-240) but not all studies (241). The effect may also be seen with other allergens (240). High-dose exposure to an inhalant allergen (birch pollen) is needed for the development of sensitization and allergic disease in high-risk children (238). The window of allergic risk may be around 3 months after birth. Exposure of the mother during pregnancy to inhalant allergens is less likely to result in sensitization in the child than exposure of the child in early infancy (242). In foods, an opposite mechanism may be found.

3 Preschool children polysensitization: Children with a family history of allergic diseases develop polysensitization and multimorbidities in early childhood. The influence of cofactors should be investigated. The disease will persist over life. Some of the children may only be monosen- sitized for a few years. One of the potential mechanisms may be associated with the C11orf30-LRRC32 region involved in the regulation of $\operatorname{IgE}$ (130), polysensitization (131), eosinophilic inflammation (132) and comorbid allergic diseases (133). Interestingly, C11orf30 interacts with the zinc finger MYND domain-containing protein 11 (ZMYND11). The protein encoded by this gene binds the adenovirus E1A protein. The protein localizes to the nucleus. It functions as a transcriptional repressor, and the expression of E1A inhibits this repression (243).

4 Polysensitization later in life: Children with or without a family history of allergic diseases develop polysensitization and multimorbidities later in childhood. The disease will persist over life. However, some of the children may only be monosensitized for a few years.

5 Monosensitization after puberty: In cypress and tree pollen allergy, many monosensitized individuals with an oligoclonal IgE response develop allergic symptoms (and probably sensitization) after puberty and sometimes a long time later. Cofactors (e.g. pollutants) may be of importance.

\section{Conclusion and implications of novel phenotypes of allergic diseases}

This review has compiled evidence that allergic diseases are frequently associated as allergic multimorbidities and that IgE polysensitization increases the risk of allergic comorbidity. Although the origin of allergic comorbidity and its link with polysensitization are still unclear, we hypothesize that the persistence or re-occurrence of foetal type 2 signalling genes plays an important role. The integration of comorbidities and polysensitization has resulted in a new classification framework of allergic diseases which could help to improve the understanding of genetic and epigenetic mechanisms of allergy as well as to better manage allergic diseases (Table 2). Asthma, rhinitis, AD and EoE are manifestations of a systemic immune imbalance, and a comprehensive approach should be taken for prevention and treatment (244).

Many of the hypotheses raised in this study can be currently tested by the novel classification of allergic diseases using data already available, in particular in the MeDALL study.

\section{Conflicts of interest}

None.

\section{References}

1. Johansson SG, Bieber T, Dahl R, Friedmann PS, Lanier BQ, Lockey RF et al. Revised nomenclature for allergy for global use: Report of the Nomenclature Review Committee of the World Allergy Organization, October 2003. J Allergy Clin Immunol 2004;113:832-836.

2. Bousquet J, Khaltaev N, Cruz AA, Denburg J, Fokkens WJ, Togias A et al.
Allergic Rhinitis and its Impact on Asthma (ARIA) 2008 update (in collaboration with the World Health Organization, GA(2) LEN and AllerGen). Allergy 2008;63(Suppl 86):8-160.

3. Bousquet J, Khaltaev N. Global Surveillance, Prevention and Control of Chronic Respiratory Diseases. A Comprehensive Approach. Global Alliance against Chronic
Respiratory Diseases. WHO: World Health Organization. ISBN 9789241563468. 2007: 148.

4. Bieber T. Atopic dermatitis. $N$ Engl J Med 2008;358:1483-1494.

5. Pearce N, Pekkanen J, Beasley R. How much asthma is really attributable to atopy? Thorax 1999;54:268-272. 
6. Weinmayr G, Forastiere F, Weiland SK, Rzehak P, Abramidze T, Annesi-Maesano I et al. International variation in prevalence of rhinitis and its relationship with sensitisation to perennial and seasonal allergens. Eur Respir J 2008;32:1250-1261.

7. Bousquet PJ, Leynaert B, Neukirch F, Sunyer J, Janson CM, Anto J et al. Geographical distribution of atopic rhinitis in the European Community Respiratory Health Survey I. Allergy 2008;63:1301-1309.

8. Bousquet J, Fokkens W, Burney P, Durham SR, Bachert C, Akdis CA et al. Important research questions in allergy and related diseases: nonallergic rhinitis: a GA2LEN paper. Allergy 2008;63:842-853.

9. Raheem M, Leach ST, Day AS, Lemberg DA. The pathophysiology of eosinophilic esophagitis. Front Pediatr 2014;2:41.

10. Virchow JC. Eosinophilic esophagitis: asthma of the esophagus? Dig Dis 2014;32:54-60.

11. Straumann A, Aceves SS, Blanchard C, Collins MH, Furuta GT, Hirano I et al. Pediatric and adult eosinophilic esophagitis: similarities and differences. Allergy 2012;67:477-490.

12. Anto JM, Pinart M, Akdis M, Auffray C, Bachert C, Basagana X et al. Understanding the complexity of IgE-related phenotypes from childhood to young adulthood: a Mechanisms of the Development of Allergy (MeDALL) seminar. J Allergy Clin Immunol 2012;129:943-954.

13. Bousquet J, Anto JM, Bachert C, Bousquet PJ, Colombo P, Crameri R et al. Factors responsible for differences between asymptomatic subjects and patients presenting an IgE sensitization to allergens. A GALEN project. Allergy 2006;61:671-680.

14. Bousquet PJ, Castelli C, Daures JP, Heinrich J, Hooper R, Sunyer J et al. Assessment of allergen sensitization in a general population-based survey (European Community Respiratory Health Survey I). Ann Epidemiol 2010;20:797-803.

15. Bousquet J, Kjellman NI. Predictive value of tests in childhood allergy. $J$ Allergy Clin Immunol 1986;78:1019-1022.

16. Coca A, Cooke R. On the classification of phenomena of hypersensitiveness. J Immunol 1923;8:163-182.

17. Pepys J. Types of allergic reaction. Clin Allergy 1973;3(Suppl):491-509.

18. Pearce N, Douwes J, Beasley R. Is allergen exposure the major primary cause of asthma? Thorax 2000;55:424-431.

19. Anto JM. The causes of asthma: the need to look at the data with different eyes. Allergy 2004;59:121-123.

20. Semic-Jusufagic A, Bachert C, Gevaert P, Holtappels G, Lowe L, Woodcock A et al. Staphylococcus aureus sensitization and allergic disease in early childhood: population-based birth cohort study. J Allergy Clin Immunol 2007;119:930-936.

21. Bachert C, Zhang N, Patou J, van Zele T, Gevaert P. Role of staphylococcal superantigens in upper airway disease. Curr Opin Allergy Clin Immunol 2008;8:34-38.

22. Bachert C, Zhang N, Holtappels G, De Lobel L, van Cauwenberge P, Liu S et al. Presence of IL-5 protein and IgE anes totibodi staphylococcal enterotoxins in nasal polyps is associated with comorbid asthma. J Allergy Clin Immunol 2010;126:962-968.

23. Kowalski ML, Cieslak M, Perez-Novo CA, Makowska JS, Bachert C. Clinical and immunological determinants of severe/ refractory asthma (SRA): association with Staphylococcal superantigen-specific IgE antibodies. Allergy 2011;66:32-38.

24. Pinart M, Benet M, Annesi-Maesano I, von Berg A, Berdel D, Carlsen KC et al. Comorbidity of eczema, rhinitis, and asthma in IgE-sensitised and non-IgE-sensitised children in MeDALL: a population-based cohort study. Lancet Respir Med 2014;2:131-140.

25. Bousquet J, Anto J, Auffray C, Akdis M, Cambon-Thomsen A, Keil T et al. MeDALL (Mechanisms of the Development of ALLergy): an integrated approach from phenotypes to systems medicine. Allergy 2011;66:596-604.

26. Bousquet J, Jorgensen C, Dauzat M, Cesario A, Camuzat T, Bourret $\mathrm{R}$ et al. Systems medicine approaches for the definition of complex phenotypes in chronic diseases and ageing. From concept to implementation and policies. Curr Pharm Des 2014;20:5928-5944.

27. Paris-Kohler A, Demoly P, Persi L, Lebel B, Bousquet J, Arnoux B. In vitro diagnosis of cypress pollen allergy by using cytofluorimetric analysis of basophils (Basotest). J Allergy Clin Immunol 2000;105:339-345.

28. Glaumann S, Nopp A, Johansson SG, Rudengren M, Borres MP, Nilsson C. Basophil allergen threshold sensitivity, CDsens, IgE-sensitization and DBPCFC in peanut-sensitized children. Allergy 2012;67:242-247.

29. Sato S, Tachimoto H, Shukuya A, Ogata M, Komata T, Imai T et al. Utility of the peripheral blood basophil histamine release test in the diagnosis of hen's egg, cow's milk, and wheat allergy in children. Int Arch Allergy Immunol 2011;155(Suppl 1):96-103

30. Dahlen B, Nopp A, Johansson SG, Eduards M, Skedinger M, Adedoyin J. Basophil allergen threshold sensitivity, $\mathrm{CD}$-sens, is a measure of allergen sensitivity in asthma. Clin Exp Allergy 2011;41:10911097.

31. Konradsen JR, Nordlund B, Nilsson OB, van Hage M, Nopp A, Hedlin G et al. High basophil allergen sensitivity (CD-sens) is associated with severe allergic asthma in children. Pediatr Allergy Immunol 2012;23:376-384

32. Wickman M, Asarnoj A, Tillander H, Andersson N, Bergstrom A, Kull I et al. Childhood-to-adolescence evolution of $\operatorname{IgE}$ antibodies to pollens and plant foods in the BAMSE cohort. J Allergy Clin Immunol 2014; 133:580-582.

33. Schoos AM, Chawes BL, Folsgaard NV, Samandari N, Bonnelykke K, Bisgaard H. Disagreement between skin prick test and specific IgE in young children. Allergy 2015;70:41-48.

34. Mehl A, Niggemann B, Keil T, Wahn U, Beyer K. Skin prick test and specific serum $\mathrm{IgE}$ in the diagnostic evaluation of suspected cow's milk and hen's egg allergy in children: does one replace the other? Clin Exp Allergy 2012;42:1266-1272.

35. Linblad J, Farr R. The incidence of positive intradermal reactions and the demonstration of skin sensitizing antibody to extracts of ragweed and dust in humans without history of rhinitis or asthma. $J$ Allergy 1961;32:392.

36. Roane J, Crawford L, Triplett F, Brasher G. Intradermal tests in nonatopic children. Ann Allergy 1968;26:443.

37. Barbee RA, Lebowitz MD, Thompson HC, Burrows B. Immediate skin-test reactivity in a general population sample. Ann Intern Med 1976;84:129-133.

38. Backer V, Ulrik CS, Hansen KK, Laursen EM, Dirksen A, Bach-Mortensen N. Atopy and bronchial responsiveness in random population sample of 527 children and adolescents. Ann Allergy 1992;69:116122.

39. Baldacci S, Modena P, Carrozzi L, Pedreschi M, Vellutini M, Biavati P et al. Skin prick test reactivity to common aeroallergens in relation to total $\mathrm{IgE}$, respiratory symptoms, and smoking in a general population sample of northern Italy. Allergy 1996;51:149-156.

40. Jansen DF, Rijcken B, Schouten JP, Kraan J, Weiss ST, Timens W et al. The relationship of skin test positivity, high serum total IgE levels, and peripheral blood eosinophilia to symptomatic and asymptomatic airway hyperresponsiveness. Am J Respir Crit Care Med 1999;159:924-931.

41. Droste JH, Kerhof M, de Monchy JG, Schouten JP, Rijcken B. Association of skin test reactivity, specific IgE, total IgE, and eosinophils with nasal symptoms in a community-based population study. The 
Dutch ECRHS Group. J Allergy Clin Immunol 1996;97:922-932.

42. Sakaida H, Masuda S, Takeuchi K. Analysis of factors influencing sensitization of Japanese cedar pollen in asymptomatic subjects. Auris Nasus Larynx 2013;40:543-547.

43. Hagy GW, Settipane GA. Risk factors for developing asthma and allergic rhinitis. A 7-year follow-up study of college students. J Allergy Clin Immunol 1976;58:330-336.

44. Rasmussen F, Siersted HC, Lambrechtsen J, Hansen HS, Hansen NC. Impact of airway lability, atopy, and tobacco smoking on the development of asthma-like symptoms in asymptomatic teenagers. Chest 2000;117:1330-1335.

45. Peat JK, Salome CM, Woolcock AJ. Longitudinal changes in atopy during a 4-year period: relation to bronchial hyperresponsiveness and respiratory symptoms in a population sample of Australian schoolchildren. J Allergy Clin Immunol 1990;85:6574.

46. Bodtger U, Poulsen LK, Malling HJ. Asymptomatic skin sensitization to birch predicts later development of birch pollen allergy in adults: a 3-year follow-up study. J Allergy Clin Immunol 2003;111:149-154.

47. Bodtger U, Poulsen LK, Linneberg A. Rhinitis symptoms and IgE sensitization as risk factors for development of later allergic rhinitis in adults. Allergy 2006;61:712-716.

48. Anto JM, Sunyer J, Basagana X, GarciaEsteban R, Cerveri I, de Marco R et al. Risk factors of new-onset asthma in adults: a population-based international cohort study. Allergy 2010;65:1021-1030.

49. von Hertzen LC, Laatikainen T, Pennanen S, Makela MJ, Haahtela T; Karelian Allergy Study G. Is house dust mite monosensitization associated with clinical disease? Allergy 2008;63:379-381.

50. Pastorello EA, Incorvaia C, Ortolani C, Bonini S, Canonica GW, Romagnani S et al. Studies on the relationship between the level of specific IgE antibodies and the clinical expression of allergy: I. Definition of levels distinguishing patients with symptomatic from patients with asymptomatic allergy to common aeroallergens. J Allergy Clin Immunol 1995;96:580-587.

51. Pastorello EA, Farioli L, Pravettoni V, Ispano M, Conti A, Ansaloni R et al. Sensitization to the major allergen of Brazil nut is correlated with the clinical expression of allergy. J Allergy Clin Immunol 1998;102:1021-1027.

52. Sampson HA. Utility of food-specific IgE concentrations in predicting symptomatic food allergy. J Allergy Clin Immunol 2001;107:891-896.

53. Boyano Martinez T, Garcia-Ara C, DiazPena JM, Munoz FM, Garcia Sanchez G,
Esteban MM. Validity of specific IgE antibodies in children with egg allergy. Clin Exp Allergy 2001;31:1464-1469.

54. Boyano-Martinez T, Garcia-Ara C, Diaz-Pena JM, Martin-Esteban M. Prediction of tolerance on the basis of quantification of egg white- specific IgE antibodies in children with egg allergy. J Allergy Clin Immunol 2002;110:304-309.

55. Nilsson N, Nilsson C, Hedlin G, Johansson SG, Borres MP, Nopp A. Combining analyses of basophil allergen threshold sensitivity, CD-sens, and $\operatorname{IgE}$ antibodies to hydrolyzed wheat, omega- 5 gliadin and timothy grass enhances the prediction of wheat challenge outcome. Int Arch Allergy Immunol 2013;162:50-57.

56. Celik-Bilgili S, Mehl A, Verstege A, Staden $\mathrm{U}$, Nocon M, Beyer K et al. The predictive value of specific immunoglobulin $\mathrm{E}$ levels in serum for the outcome of oral food challenges. Clin Exp Allergy 2005;35:268-273.

57. Verstege A, Mehl A, Rolinck-Werninghaus C, Staden U, Nocon M, Beyer K et al. The predictive value of the skin prick test weal size for the outcome of oral food challenges. Clin Exp Allergy 2005;35:1220-1226.

58. Peters RL, Allen KJ, Dharmage SC, Tang ML, Koplin JJ, Ponsonby AL et al. Skin prick test responses and allergen-specific $\mathrm{IgE}$ levels as predictors of peanut, egg, and sesame allergy in infants. J Allergy Clin Immunol 2013;132:874-880.

59. Cabauatan CR, Lupinek C, Scheiblhofer S, Weiss R, Focke-Tejkl M, Bhalla PL et al. Allergen microarray detects high prevalence of asymptomatic IgE sensitizations to tropical pollen-derived carbohydrates. J Allergy Clin Immunol 2014;133:910-914.

60. Altmann F. The role of protein glycosylation in allergy. Int Arch Allergy Immunol 2007;142:99-115.

61. Holzweber F, Svehla E, Fellner W, Dalik T, Stubler S, Hemmer W et al. Inhibition of IgE binding to cross-reactive carbohydrate determinants enhances diagnostic selectivity. Allergy 2013;68:1269-1277.

62. Wollmann E, Hamsten C, Sibanda E, Ochome M, Focke-Tejkl M, Asarnoj A et al. Natural clinical tolerance to peanut in African patients is caused by poor allergenic activity of peanut IgE. Allergy 2015; 70:638-652.

63. Hahn EL, Bacharier LB. The atopic march: the pattern of allergic disease development in childhood. Immunol Allergy Clin North Am 2005;25:231-246.

64. Spergel JM. Epidemiology of atopic dermatitis and atopic march in children. Immunol Allergy Clin North Am 2010;30:269-280.

65. Belgrave DC, Granell R, Simpson A, Guiver J, Bishop C, Buchan I et al. Developmental profiles of eczema, wheeze, and rhinitis: two population-based birth cohort studies. PLoS Med 2014; doi: 10.1371/journal.pmed.1001748.

66. Hovland V, Riiser A, Mowinckel P, Carlsen KH, Carlsen KC. Asthma with allergic comorbidities in adolescence is associated with bronchial responsiveness and airways inflammation. Pediatr Allergy Immunol 2014;25:351-359.

67. Ziyab AH, Raza A, Karmaus W, Tongue $\mathrm{N}$, Zhang H, Matthews S et al. Trends in eczema in the first 18 years of life: results from the Isle of Wight 1989 birth cohort study. Clin Exp Allergy 2010;40:1776-1784.

68. Tronnes H, Wilcox AJ, Lie RT, Markestad T, Moster D. The association of preterm birth with severe asthma and atopic dermatitis: a national cohort study. Pediatr Allergy Immunol 2013;24:782-787.

69. Ballardini N, Kull I, Soderhall C, Lilja G, Wickman M, Wahlgren CF. Eczema severity in preadolescent children and its relation to sex, filaggrin mutations, asthma, rhinitis, aggravating factors and topical treatment: a report from the BAMSE birth cohort. $\mathrm{Br} J$ Dermatol 2013;168:588-594.

70. Lodrup Carlsen KC, Mowinckel P, Hovland V, Haland G, Riiser A, Carlsen $\mathrm{KH}$. Lung function trajectories from birth through puberty reflect asthma phenotypes with allergic comorbidity. J Allergy Clin Immunol 2014;134:917-923.

71. Ferreira MA, Matheson MC, Tang CS, Granell R, Ang W, Hui J et al. Genomewide association analysis identifies 11 risk variants associated with the asthma with hay fever phenotype. J Allergy Clin Immunol 2014;133:1564-1571.

72. Bresciani M, Paradis L, Des Roches A, Vernhet H, Vachier I, Godard P et al. Rhinosinusitis in severe asthma. $J$ Allergy Clin Immunol 2001;107:73-80.

73. Akdis CA, Bachert C, Cingi C, Dykewicz MS, Hellings PW, Naclerio RM et al. Endotypes and phenotypes of chronic rhinosinusitis: a PRACTALL document of the European Academy of Allergy and Clinical Immunology and the American Academy of Allergy, Asthma \& Immunology. J Allergy Clin Immunol 2013;131: 1479-1490.

74. de Jong AB, Dikkeschei LD, Brand PL. Sensitization patterns to food and inhalant allergens in childhood: a comparison of non-sensitized, monosensitized, and polysensitized children. Pediatr Allergy Immunol 2011;22:166-171.

75. Pepys J. "Atopy": a study in definition. Allergy 1994;49:397-399.

76. Valenta R, Duchene M, Ebner C, Valent P, Sillaber C, Deviller P et al. Profilins constitute a novel family of functional plant panallergens. J Exp Med 1992;175:377-385. 
77. Ciprandi G, Cirillo I. Monosensitization and polysensitization in allergic rhinitis. Eur J Intern Med 2011;22:e75-e79.

78. de Bot CM, Roder E, Pols DH, Bindels PJ, van Wijk RG, van der Wouden JC et al. Sensitisation patterns and association with age, gender, and clinical symptoms in children with allergic rhinitis in primary care: a cross-sectional study. Prim Care Respir J 2013;22:155-160.

79. Brunst KJ, Ryan PH, Lockey JE, Bernstein DI, McKay RT, Khurana Hershey GK et al. Unraveling the relationship between aeroallergen sensitization, gender, secondhand smoke exposure, and impaired lung function. Pediatr Allergy Immunol 2012;23:479-487.

80. Simpson A, Tan VY, Winn J, Svensen M, Bishop CM, Heckerman DE et al. Beyond atopy: multiple patterns of sensitization in relation to asthma in a birth cohort study. Am J Respir Crit Care Med 2010;181:12001206.

81. Pauli G. Evolution in the understanding of cross-reactivities of respiratory allergens: the role of recombinant allergens. Int Arch Allergy Immunol 2000;123:183-195.

82. Thomas WR, Hales BJ, Smith WA. House dust mite allergens in asthma and allergy. Trends Mol Med 2010;16:321-328.

83. Gadermaier G, Hauser M, Ferreira F. Allergens of weed pollen: an overview on recombinant and natural molecules. Methods 2014;66:55-66.

84. Nilsson OB, van Hage M, Gronlund H. Mammalian-derived respiratory allergens implications for diagnosis and therapy of individuals allergic to furry animals. Methods 2014;66:86-95.

85. Passalacqua G, Melioli G, Bonifazi F, Bonini S, Maggi E, Senna $G$ et al. The additional values of microarray allergen assay in the management of polysensitized patients with respiratory allergy. Allergy 2013;68:1029-1033.

86. van Ree R, Chapman MD, Ferreira F, Vieths S, Bryan D, Cromwell O et al. The CREATE project: development of certified reference materials for allergenic products and validation of methods for their quantification. Allergy 2008;63:310-326.

87. Valenta R, Ferreira F, Focke-Tejkl M, Linhart B, Niederberger V, Swoboda I et al. From allergen genes to allergy vaccines. Annu Rev Immunol 2010;28:211-241.

88. Canonica GW, Ansotegui IJ, Pawankar R, Schmid-Grendelmeier P, van Hage M, Baena-Cagnani CE et al. A WAO - ARIA GA(2)LEN consensus document on molecular-based allergy diagnostics. World Allergy Organ J 2013;6:17.

89. Andersen MB, Hall S, Dragsted LO. Identification of European allergy patterns to the allergen families PR-10, LTP, and profilin from Rosaceae fruits. Clin Rev Allergy Immunol 2011:41:4-19.

90. Boulet LP, Turcotte H, Laprise C, Lavertu C, Bedard PM, Lavoie A et al. Comparative degree and type of sensitization to common indoor and outdoor allergens in subjects with allergic rhinitis and/or asthma. Clin Exp Allergy 1997;27:52-59.

91. Canova C, Heinrich J, Anto JM, Leynaert B, Smith M, Kuenzli N et al. The influence of sensitisation to pollens and moulds on seasonal variations in asthma attacks. Eur Respir J 2013;42:935-945.

92. Sears MR, Burrows B, Flannery EM, Herbison GP, Holdaway MD. Atopy in childhood. I. Gender and allergen related risks for development of hay fever and asthma. Clin Exp Allergy 1993;23:941-948.

93. Bousquet J, Coulomb Y, Arrendal H, Robinet-Levy M, Michel FB. Total serum IgE concentrations in adolescents and adults using the phadebas IgE PRIST technique. Allergy 1982;37:397-406.

94. Kauffmann F, Dizier MH, Annesi-Maesano I, Bousquet J, Charpin D, Demenais F et al. EGEA (Epidemiological study on the Genetics and Environment of Asthma, bronchial hyperresponsiveness and atopy) descriptive characteristics. Clin Exp Allergy 1999;29(Suppl 4):17-21.

95. Bousquet J, Van Cauwenberge P, Khaltaev N. Allergic rhinitis and its impact on asthma. J Allergy Clin Immunol 2001;108(5 Suppl):S147-S334.

96. Cruz AA, Popov T, Pawankar R, AnnesiMaesano I, Fokkens W, Kemp J et al. Common characteristics of upper and lower airways in rhinitis and asthma: ARIA update, in collaboration with GA(2)LEN. Allergy 2007;62(Suppl 84):1-41.

97. Leynaert B, Bousquet J, Henry C, Liard R, Neukirch F. Is bronchial hyperresponsiveness more frequent in women than in men? A population-based study. Am J Respir Crit Care Med 1997;156:1413-1420.

98. Bousquet J, Hejjaoui A, Becker WM, Cour P, Chanal I, Lebel B et al. Clinical and immunologic reactivity of patients allergic to grass pollens and to multiple pollen species. I. Clinical and immunologic characteristics. J Allergy Clin Immunol 1991;87:737746

99. Bousquet J, Becker WM, Hejjaoui A, Chanal I, Lebel B, Dhivert $\mathrm{H}$ et al. Differences in clinical and immunologic reactivity of patients allergic to grass pollens and to multiple-pollen species. II. Efficacy of a double-blind, placebo-controlled, specific immunotherapy with standardized extracts. J Allergy Clin Immunol 1991;88:43-53.

100. Ciprandi G, Alesina R, Ariano R, Aurnia $P$, Borrelli $P$, Cadario $G$ et al. Char- acteristics of patients with allergic polysensitization: the POLISMAIL study. Eur Ann Allergy Clin Immunol 2008;40:77-83.

101. Peternel R, Milanovic SM, Hrga I, Mileta $\mathrm{T}$, Culig J. Incidence of Betulaceae pollen and pollinosis in Zagreb, Croatia, 20022005. Ann Agric Environ Med 2007;14:8791.

102. Asero R. Ragweed allergy in northern Italy: are patterns of sensitization changing? Eur Ann Allergy Clin Immunol 2012;44:157159.

103. Konradsen JR, Nordlund B, Onell A, Borres MP, Gronlund H, Hedlin G. Severe childhood asthma and allergy to furry animals: refined assessment using molecularbased allergy diagnostics. Pediatr Allergy Immunol 2014;25:187-192.

104. Fasce L, Tosca MA, Baroffio M, Olcese R, Ciprandi G. Atopy in wheezing infants always starts with monosensitization. Allergy Asthma Proc 2007;28:449-453.

105. Hatzler L, Panetta V, Lau S, Wagner P, Bergmann RL, Illi S et al. Molecular spreading and predictive value of preclinical IgE response to Phleum pratense in children with hay fever. $J$ Allergy Clin Immunol 2012;130:894-901.

106. Westman M, Lupinek C, Bousquet J, Andersson N, Pahr S, Baar A et al. Early childhood IgE reactivity to pathogenesisrelated class 10 proteins predicts allergic rhinitis in adolescence. $J$ Allergy Clin Immunol 2015;135:1199-1206.

107. Just J, Deslandes-Boutmy E, Amat F, Desseaux K, Nemni A, Bourrat E et al. Natural history of allergic sensitization in infants with early-onset atopic dermatitis: results from ORCA Study. Pediatr Allergy Immunol 2014;25:668-673.

108. Lazic N, Roberts G, Custovic A, Belgrave D, Bishop CM, Winn J et al. Multiple atopy phenotypes and their associations with asthma: similar findings from two birth cohorts. Allergy 2013;68:764-770.

109. Hatzler L, Panetta V, Illi S, Hofmaier S, Rohrbach A, Hakimeh D et al. Parental hay fever reinforces $\mathrm{IgE}$ to pollen as pre-clinical biomarker of hay fever in childhood. Pediatr Allergy Immunol 2014;25:366-373.

110. Ramirez DA. The natural history of mountain cedar pollinosis. J Allergy Clin Immunol 1984;73:88-93.

111. Bousquet J, Knani J, Hejjaoui A, Ferrando R, Cour P, Dhivert H et al. Heterogeneity of atopy. I. Clinical and immunologic characteristics of patients allergic to cypress pollen. Allergy 1993;48:183-188.

112. Silvestri M, Rossi GA, Cozzani S, Pulvirenti G, Fasce L. Age-dependent tendency to become sensitized to other classes 
of aeroallergens in atopic asthmatic children. Ann Allergy Asthma Immunol 1999;83:335-340.

113. Asero R. Birch and ragweed pollinosis north of Milan: a model to investigate the effects of exposure to "new" airborne allergens. Allergy 2002;57:1063-1066.

114. Lee JH, Noh G. Clinical significance and evaluation of polysensitisation using skin sensitisation profiling in atopic dermatitis. Inflamm Allergy Drug Targets 2013;12:212 220.

115. Rudin A, Macaubas C, Wee C, Holt BJ, Slya PD, Holt PG. "Bystander" amplification of PBMC cytokine responses to seasonal allergen in polysensitized atopic children. Allergy 2001;56:1042-1048.

116. Pene J, Rivier A, Lagier B, Becker WM, Michel FB, Bousquet J. Differences in IL4 release by PBMC are related with heterogeneity of atopy. Immunology 1994;81:58-64.

117. Skrindo I, Lupinek C, Valenta R, Hovland V, Pahr S, Baar A et al. The use of the MeDALL-chip to assess IgE sensitization, a new diagnostic tool for allergic disease?. Pediatr Allergy Immunol 2015;26: 239-246.

118. Bousquet J, Anto JM, Bachert C, Bousquet PJ, Colombo P, Crameri R et al. http://www.ncbi.nlm.nih.gov/pubmed/ 16677235 Factors responsible for differences between asymptomatic subjects and patients presenting an IgE sensitization to allergens. A GA2LEN project. Allergy. 2006;61:671-680.

119. Marsh DG, Neely JD, Breazeale DR, Ghosh B, Freidhoff LR, Ehrlich-Kautzky E et al. Linkage analysis of IL4 and other chromosome 5q31.1 markers and total serum immunoglobulin E concentrations. Science 1994;264:1152-1156.

120. Fischer GF, Pickl WF, Fae I, Ebner C, Ferreira F, Breiteneder $\mathrm{H}$ et al. Association between $\mathrm{IgE}$ response against Bet v I, the major allergen of birch pollen, and HLADRB alleles. Hum Immunol 1992;33:259_ 265

121. Tautz C, Rihs HP, Thiele A, Zwollo P, Freidhoff LR, Marsh DG et al. Association of class II sequences encoding DR1 and DQ5 specificities with hypersensitivity to chironomid allergen Chi t I. J Allergy Clin Immunol 1994;93:918-925.

122. Soriano JB, Ercilla G, Sunyer J, Real FX, Lazaro C, Rodrigo MJ et al. HLA class II genes in soybean epidemic asthma patients. Am J Respir Crit Care Med 1997;156:1394 1398.

123. D'Amato M, Scotto d'Abusco A, Maggi E, Menna T, Sacerdoti G, Maurizio SM et al. Association of responsiveness to the major pollen allergen of Parietaria officinalis with
HLA-DRB 1 * alleles: a multicenter study. Human Immunol 1996;46:100-106.

124. Marsh DG, Chase GA, Freidhoff LR, Meyers DA, Bias WB. Association of HLA antigens and total serum immunoglobulin $E$ level with allergic response and failure to respond to ragweed allergen Ra3. Proc Natl Acad Sci U S A 1979;76:2903-2907.

125. Hong X, Hao K, Ladd-Acosta C, Hansen KD, Tsai HJ, Liu X et al. Genome-wide association study identifies peanut allergyspecific loci and evidence of epigenetic mediation in US children. Nat Commun 2015;6:6304.

126. Doherty DG, Penzotti JE, Koelle DM, Kwok WW, Lybrand TP, Masewicz S et al. Structural basis of specificity and degeneracy of $\mathrm{T}$ cell recognition: pluriallelic restriction of $\mathrm{T}$ cell responses to a peptide antigen involves both specific and promiscuous interactions between the $\mathrm{T}$ cell receptor, peptide, and HLA-DR. $J$ Immunol 1998;161:3527-3535.

127. Joshi SK, Suresh PR, Chauhan VS. Flexibility in MHC and TCR recognition: degenerate specificity at the $\mathrm{T}$ cell level in the recognition of promiscuous Th epitopes exhibiting no primary sequence homology. J Immunol 2001;166:6693-6703.

128. D'Amato M, Picardi A, Menna T, Di Somma C, Ariano R, di Pietro A et al. HLADRB1* and allergy to Parietaria: linkage and association analyses. Hum Immunol 1999;60:1250-1258.

129. Cardaba B, Cortegano I, Florido F, Arrieta I, Aceituno E, del Pozo V et al. Genetic restrictions in olive pollen allergy. $J$ Allergy Clin Immunol 2000;105:292-298.

130. Li X, Ampleford EJ, Howard TD, Moore WC, Li H, Busse WW et al. The C11orf30LRRC32 region is associated with total serum IgE levels in asthmatic patients. $J$ Allergy Clin Immunol 2012;129:575-578.

131. Amaral AF, Minelli C, Guerra S, Wjst M, Probst-Hensch N, Pin I et al. The locus C11orf30 increases susceptibility to polysensitization. Allergy 2015;70:328-333.

132. Sleiman PM, Wang ML, Cianferoni A, Aceves S, Gonsalves N, Nadeau K et al. GWAS identifies four novel eosinophilic esophagitis loci. Nat Commun 2014;5:5593.

133. Tamari M, Tanaka S, Hirota T. Genomewide association studies of allergic diseases. Allergol Int 2013;62:21-28.

134. Liang L, Willis-Owen SA, Laprise C, Wong KC, Davies GA, Hudson TJ et al. An epigenome-wide association study of total serum immunoglobulin E concentration. Nature 2015;520:670-674.

135. Larsen W. Development of the head and neck. In: Larsen editor. Human Embryology. New York: Churchill-Livingstone, 2001: 351-371.
136. Visscher M, Narendran V. The ontogeny of skin. Adv Wound Care 2014;3:291-303.

137. Kitaoka H, Burri PH, Weibel ER. Development of the human fetal airway tree: analysis of the numerical density of airway endtips. Anat Rec 1996;244:207-213.

138. Noisa P, Raivio T. Neural crest cells: from developmental biology to clinical interventions. Birth Defects Res C Embryo Today 2014;102:263-274.

139. Bonnans C, Chou J, Werb Z. Remodelling the extracellular matrix in development and disease. Nat Rev Mol Cell Biol 2014; 15:786-801.

140. Haugen AC, Schug TT, Collman G, Heindel JJ. Evolution of DOHaD: the impact of environmental health sciences. J Dev Orig Health Dis 2015;6:55-64.

141. Bousquet J, Anto JM, Berkouk K, Gergen P, Pinto Antunes J, Auge P et al. Developmental determinants in non-communicable chronic diseases and ageing. Thorax 2015;70:595-597.

142. Gluckman PD, Hanson MA, Buklijas T. A conceptual framework for the developmental origins of health and disease. J Dev Orig Health Dis 2010;1:6-18.

143. Hanson MA, Gluckman PD. Early developmental conditioning of later health and disease: physiology or pathophysiology? Physiol Rev 2014;94:1027-1076.

144. Richmond CA, Breault DT. Regulation of gene expression in the intestinal epithelium. Prog Mol Biol Transl Sci 2010;96:207-229.

145. Endo T, Kusakabe M, Sunadome K, Yamamoto T, Nishida E. The kinase SGK1 in the endoderm and mesoderm promotes ectodermal survival by down-regulating components of the death-inducing signaling complex. Sci Signal 2011;4:ra2.

146. Li X, Hawkins GA, Ampleford EJ, Moore WC, Li H, Hastie AT et al. Genome-wide association study identifies TH1 pathway genes associated with lung function in asthmatic patients. $J$ Allergy Clin Immunol 2013;132:313-320

147. Li X, Howard TD, Moore WC, Ampleford EJ, Li H, Busse WW et al. Importance of hedgehog interacting protein and other lung function genes in asthma. $J$ Allergy Clin Immunol 2011;127:1457-1465.

148. Barouki R, Gluckman PD, Grandjean P, Hanson M, Heindel JJ. Developmental origins of non-communicable disease: implications for research and public health. Environ Health 2012;11:42.

149. Sykes L, MacIntyre DA, Yap XJ, Teoh TG, Bennett PR. The Th1:th2 dichotomy of pregnancy and preterm labour. Mediators Inflamm 2012;2012:967629.

150. Saito S, Nakashima A, Shima T, Ito M. Th1/Th2/Th17 and regulatory T-cell para- 
digm in pregnancy. Am $J$ Reprod Immunol 2010;63:601-610.

151. Lisciandro JG, Prescott SL, Nadal-Sims MG, Devitt CJ, Pomat W, Siba PM et al. Comparison of neonatal $\mathrm{T}$ regulatory cell function in Papua New Guinean and Australian newborns. Pediatr Allergy Immunol 2012;23:173-180.

152. Lisciandro JG, Prescott SL, Nadal-Sims MG, Devitt CJ, Richmond PC, Pomat W et al. Neonatal antigen-presenting cells are functionally more quiescent in children born under traditional compared with modern environmental conditions. J Allergy Clin Immunol 2012;130:1167-1174.

153. Michel FB, Bousquet J, Greillier P, Robinet-Levy M, Coulomb Y. Comparison of cord blood immunoglobulin E concentrations and maternal allergy for the prediction of atopic diseases in infancy. $J$ Allergy Clin Immunol 1980;65:422-430.

154. Kamemura N, Tada H, Shimojo N, Morita $\mathrm{Y}$, Kohno Y, Ichioka $\mathrm{T}$ et al. Intrauterine sensitization of allergen-specific IgE analyzed by a highly sensitive new allergen microarray. J Allergy Clin Immunol 2012;130:113-121.

155. Nissen SP, Kjaer HF, Host A, Nielsen J, Halken S. Can family history and cord blood IgE predict sensitization and allergic diseases up to adulthood? Pediatr Allergy Immunol 2015;26:42-48.

156. Kamemura N, Kawamoto N, Nakamura R, Teshima R, Fukao T, Kido H. Lowaffinity allergen-specific $\mathrm{IgE}$ in cord blood and affinity maturation after birth. $J$ Allergy Clin Immunol 2014;133:904-905.

157. Prescott SL, Macaubas C, Smallacombe T, Holt BJ, Sly PD, Holt PG. Development of allergen-specific T-cell memory in atopic and normal children. Lancet 1999;353:196200.

158. Casaca VI, Illi S, Klucker E, Ballenberger N, Schedel M, von Mutius E et al. STAT6 polymorphisms are associated with neonatal regulatory $\mathrm{T}$ cells and cytokines and atopic diseases at 3 years. Allergy 2013;68:1249-1258.

159. Macaubas C, de Klerk NH, Holt BJ, Wee C, Kendall G, Firth M et al. Association between antenatal cytokine production and the development of atopy and asthma at age 6 years. Lancet 2003;362:1192-1197.

160. Herberth G, Heinrich J, Roder S, Figl A, Weiss M, Diez U et al. Reduced IFNgamma- and enhanced IL-4-producing CD4+ cord blood $\mathrm{T}$ cells are associated with a higher risk for atopic dermatitis during the first $2 \mathrm{yr}$ of life. Pediatr Allergy Immunol 2010;21:5-13.

161. van der Velden VH, Laan MP, Baert MR, de Waal Malefyt R, Neijens HJ, Savelkoul HF. Selective development of a strong Th2 cytokine profile in high-risk children who develop atopy: risk factors and regulatory role of IFN-gamma, IL-4 and IL-10. Clin Exp Allergy 2001;31:997-1006.

162. Rothers J, Halonen M, Stern DA, Lohman IC, Mobley S, Spangenberg A et al. Adaptive cytokine production in early life differentially predicts total IgE levels and asthma through age 5 years. $J$ Allergy Clin Immunol 2011;128:397-402.

163. Bousquet J, Gern JE, Martinez FD, Anto JM, Johnson CC, Holt PG et al. Birth cohorts in asthma and allergic diseases: report of a NIAID/NHLBI/MeDALL joint workshop. J Allergy Clin Immunol 2014;133:1535-1546.

164. Walker ML, Holt KE, Anderson GP, Teo SM, Sly PD, Holt PG et al. Elucidation of pathways driving asthma pathogenesis: development of a systems-level analytic strategy. Front Immunol 2014;5:447.

165. Sharma S, Tantisira K, Carey V, Murphy AJ, Lasky-Su J, Celedon JC et al. A role for Wnt signaling genes in the pathogenesis of impaired lung function in asthma. Am J Respir Crit Care Med 2010;181:328-336.

166. MacIntyre EA, Brauer M, Melen E, Bauer CP, Bauer M, Berdel D et al. GSTP1 and TNF gene variants and associations between air pollution and incident childhood asthma: the traffic, asthma and genetics (TAG) study. Environ Health Perspect 2014;122:418-424.

167. Heijink IH, Nawijn MC, Hackett TL. Airway epithelial barrier function regulates the pathogenesis of allergic asthma. Clin Exp Allergy 2014;44:620-630.

168. Holgate ST. The sentinel role of the airway epithelium in asthma pathogenesis. Immunol Rev 2011;242:205-219.

169. Todd MD, Grusby MJ, Lederer JA, Lacy E, Lichtman AH, Glimcher LH. Transcription of the interleukin 4 gene is regulated by multiple promoter elements. J Exp Med 1993;177:1663-1674.

170. Marschan E, Honkanen J, Kukkonen K, Kuitunen M, Savilahti E, Vaarala O. Increased activation of GATA-3, IL-2 and IL-5 of cord blood mononuclear cells in infants with IgE sensitization. Pediatr Allergy Immunol 2008;19:132-139.

171. Bousquet J, Yssel H, Vignola AM. Is allergic asthma associated with delayed fetal maturation or the persistence of conserved fetal genes? Allergy 2000;55:1194-1197.

172. Melen E, Kho AT, Sharma S, Gaedigk R, Leeder JS, Mariani TJ et al. Expression analysis of asthma candidate genes during human and murine lung development. Respir Res 2011;12:86.

173. Wagener AH, Zwinderman AH, Luiten S, Fokkens WJ, Bel EH, Sterk PJ et al. The impact of allergic rhinitis and asthma on human nasal and bronchial epithelial gene expression. PLOS ONE 2013;8:e80257.

174. Brown SJ, McLean WH. One remarkable molecule: filaggrin. J Invest Dermatol 2012;132:751-762.

175. Saatian B, Rezaee F, Desando S, Emo J, Chapman T, Knowlden $\mathrm{S}$ et al. Interleukin4 and interleukin-13 cause barrier dysfunction in human airway epithelial cells. Tissue Barriers 2013;1:e24333.

176. Sato T, Liu X, Basma H, Togo S, Sugiura $\mathrm{H}$, Nelson A et al. IL-4 induces differentiation of human embryonic stem cells into fibrogenic fibroblast-like cells. J Allergy Clin Immunol 2011;127:1595-1603.

177. Gruzieva O, Merid SK, Melen E. An update on epigenetics and childhood respiratory diseases. Paediatr Respir Rev 2014; 15:348-354.

178. Bousquet J, Jacot W, Yssel H, Vignola AM, Humbert M. Epigenetic inheritance of fetal genes in allergic asthma. Allergy 2004;59:138-147.

179. Almouzni G, Altucci L, Amati B, Ashley $\mathrm{N}$, Baulcombe D, Beaujean $\mathrm{N}$ et al. Relationship between genome and epigenomechallenges and requirements for future research. BMC Genom 2014;15:487.

180. Bousquet J, Jeffery PK, Busse WW, Johnson M, Vignola AM. Asthma. From bronchoconstriction to airways inflammation and remodeling. Am J Respir Crit Care Med 2000;161:1720-1745.

181. Lambrecht BN, Hammad H. Asthma: the importance of dysregulated barrier immunity. Eur J Immunol 2013;43:3125-3137.

182. Lambrecht BN, Hammad H. The immunology of asthma. Nat Immunol 2014;16:45-56.

183. Akdis CA, Akdis M. Mechanisms of immune tolerance to allergens: role of IL10 and Tregs. J Clin Investig 2014;124:4678-4680.

184. Cianferoni A, Spergel J. The importance of TSLP in allergic disease and its role as a potential therapeutic target. Exp Rev Clin Immunol 2014;10:1463-1474.

185. Romeo MJ, Agrawal R, Pomes A, Woodfolk JA. A molecular perspective on $\mathrm{TH} 2$ promoting cytokine receptors in patients with allergic disease. J Allergy Clin Immunol 2014;133:952-960.

186. Wenzel SE. Asthma phenotypes: the evolution from clinical to molecular approaches. Nat Med 2012;18:716-725.

187. Woodruff PG, Modrek B, Choy DF, Jia G, Abbas AR, Ellwanger A et al. T-helper type 2-driven inflammation defines major subphenotypes of asthma. Am J Respir Crit Care Med 2009;180:388-395.

188. Chang YJ, DeKruyff RH, Umetsu DT. The role of type 2 innate lymphoid cells in asthma. J Leukoc Biol 2013;94: 933-940. 
189. Davies DE. Epithelial barrier function and immunity in asthma. Ann Am Thorac Soc 2014;11(Suppl 5):S244-S251.

190. Campbell AM, Chanez P, Vignola AM, Bousquet J, Couret I, Michel FB et al. Functional characteristics of bronchial epithelium obtained by brushing from asthmatic and normal subjects. Am Rev Respir Dis 1993;147:529-534.

191. Carayol N, Vachier I, Campbell A, Crampette L, Bousquet J, Godard P et al. Regulation of E-cadherin expression by dexamethasone and tumour necrosis factor-alpha in nasal epithelium. Eur Respir J 2002;20:1430-1436.

192. Divekar R, Kita H. Recent advances in epithelium-derived cytokines (IL-33, IL-25, and thymic stromal lymphopoietin) and allergic inflammation. Curr Opin Allergy Clin Immunol 2015;15:98-103.

193. Chanez P, Vignola AM, Vic P, Guddo F, Bonsignore $\mathrm{G}$, Godard $\mathrm{P}$ et al. Comparison between nasal and bronchial inflammation in asthmatic and control subjects. Am J Respir Crit Care Med 1999;159. 588-595.

194. Fuertes E, Soderhall C, Acevedo N, Becker A, Brauer M, Chan-Yeung M et al. Associations between the $17 \mathrm{q} 21$ region and allergic rhinitis in 5 birth cohorts. $J$ Allergy Clin Immunol 2015;135:573-576.

195. Wenzel S, Ford L, Pearlman D, Spector S, Sher L, Skobieranda F et al. Dupilumab in persistent asthma with elevated eosinophil levels. N Engl J Med 2013;368:2455-2466.

196. Bousquet J, Chanez P, Lacoste JY, White R, Vic P, Godard P et al. Asthma: a disease remodeling the airways. Allergy 1992;47:3-11.

197. Bousquet J, Jacquot W, Vignola AM, Bachert C, Van Cauwenberge P. Allergic rhinitis: a disease remodeling the upper airways? J Allergy Clin Immunol 2004; 113:43-49.

198. Van Bruaene N, Bachert C. Tissue remodeling in chronic rhinosinusitis. Curr Opin Allergy Clin Immunol 2011;11:8-11.

199. Blanchard C, Stucke EM, Rodriguez-Jimenez B, Burwinkel K, Collins MH, Ahrens A et al. A striking local esophageal cytokine expression profile in eosinophilic esophagitis. J Allergy Clin Immunol 2011;127:208-217

200. Straumann A, Conus S, Degen L, Felder S, Kummer M, Engel $\mathrm{H}$ et al. Budesonide is effective in adolescent and adult patients with active eosinophilic esophagitis. Gastroenterology 2010;139:1526-1537.

201. Simon HU, Straumann A. Immunopathogenesis of eosinophilic esophagitis. Dig Dis 2014;32:11-14

202. Straumann A, Spichtin HP, Bucher KA, Heer P, Simon HU. Eosinophilic esophagi- tis: red on microscopy, white on endoscopy. Digestion 2004;70:109-116.

203. Simon D, Radonjic-Hosli S, Straumann A, Yousefi S, Simon HU. Active eosinophilic esophagitis is characterized by epithelial barrier defects and eosinophil extracellular trap formation. Allergy 2015;70:443-452.

204. Izuhara K, Arima K, Ohta S, Suzuki S, Inamitsu M, Yamamoto K. Periostin in allergic inflammation. Allergol Int 2014;63:143-151.

205. Parulekar AD, Atik MA, Hanania NA. Periostin, a novel biomarker of TH2-driven asthma. Curr Opin Pulm Med 2014;20:6065.

206. Ishida A, Ohta N, Suzuki Y, Kakehata S, Okubo K, Ikeda $\mathrm{H}$ et al. Expression of pendrin and periostin in allergic rhinitis and chronic rhinosinusitis. Allergol Int 2012;61:589-595.

207. Leung DY, Guttman-Yassky E. Deciphering the complexities of atopic dermatitis: shifting paradigms in treatment approaches. J Allergy Clin Immunol 2014;134:769-779.

208. Elias PM, Wakefield JS. Mechanisms of abnormal lamellar body secretion and the dysfunctional skin barrier in patients with atopic dermatitis. J Allergy Clin Immunol 2014; 134:781-791.

209. van Ginkel CD, Flokstra-de Blok BM, Kollen BJ, Kukler J, Koppelman GH, Dubois AE. Loss-of-function variants of the filaggrin gene are associated with clinical reactivity to foods. Allergy 2015;70:461464.

210. Ziyab AH, Karmaus W, Zhang H, Holloway JW, Steck SE, Ewart S et al. Association of filaggrin variants with asthma and rhinitis: is eczema or allergic sensitization status an effect modifier? Int Arch Allergy Immunol 2014;164:308-318.

211. Marenholz I, Kerscher T, Bauerfeind A, Esparza-Gordillo J, Nickel R, Keil T et al. An interaction between filaggrin mutations and early food sensitization improves the prediction of childhood asthma. J Allergy Clin Immunol 2009;123:911-916.

212. Eyerich K, Novak N. Immunology of atopic eczema: overcoming the Th1/Th2 paradigm. Allergy 2013;68:974-982.

213. Kou K, Okawa T, Yamaguchi Y, Ono J, Inoue $\mathrm{Y}, \mathrm{Kohno} \mathrm{M}$ et al. Periostin levels correlate with disease severity and chronicity in patients with atopic dermatitis. $\mathrm{Br} \mathrm{J}$ Dermatol 2014;171:283-291.

214. Yamaguchi Y. Periostin in skin tissue and skin-related diseases. Allergol Int 2014;63:161-170.

215. Beck LA, Thaci D, Hamilton JD, Graham NM, Bieber T, Rocklin R et al. Dupilumab treatment in adults with moderate-to-severe atopic dermatitis. $N$ Engl J Med 2014;371:130-139.
216. Hamilton JD, Suarez-Farinas M, Dhingra N, Cardinale I, Li X, Kostic A et al. Dupilumab improves the molecular signature in skin of patients with moderate-to-severe atopic dermatitis. J Allergy Clin Immunol 2014;134:1293-1300.

217. Lin SK, Sabharwal G, Ghaffari G. A review of the evidence linking eosinophilic esophagitis and food allergy. Allergy Asthma Proc 2015;36:26-33.

218. Rothenberg ME. Molecular, genetic, and cellular bases for treating eosinophilic esophagitis. Gastroenterology 2015;148:1143-1157.

219. Behrendt H, Alessandrini F, Buters J, Kramer U, Koren H, Ring J. Environmental pollution and allergy: historical aspects. Chem Immunol Allergy 2014;100:268-277.

220. Anto JM, Sunyer J, Newman Taylor AJ. Comparison of soybean epidemic asthma and occupational asthma. Thorax 1996;51:743-749.

221. Charpin D, Calleja M, Lahoz C, Pichot C, Waisel Y. Allergy to cypress pollen. Allergy 2005;60:293-301.

222. Beeh KM, Ksoll M, Buhl R. Elevation of total serum immunoglobulin $\mathrm{E}$ is associated with asthma in nonallergic individuals. Eur Respir J 2000;16:609-614.

223. Moore WC, Meyers DA, Wenzel SE, Teague WG, Li H, Li X et al. Identification of asthma phenotypes using cluster analysis in the Severe Asthma Research Program. Am J Respir Crit Care Med 2010;181:315-323.

224. Gevaert P, Nouri-Aria KT, Wu H, Harper CE, Takhar P, Fear DJ et al. Local receptor revision and class switching to $\operatorname{IgE}$ in chronic rhinosinusitis with nasal polyps. Allergy 2013;68:55-63.

225. Zhang N, Holtappels G, Gevaert P, Patou J, Dhaliwal B, Gould H et al. Mucosal tissue polyclonal $\mathrm{IgE}$ is functional in response to allergen and SEB. Allergy 2011;66:141148.

226. Tomassen P, Jarvis D, Newson R, Van Ree R, Forsberg B, Howarth P et al. Staphylococcus aureus enterotoxin-specific IgE is associated with asthma in the general population: a GA(2)LEN study. Allergy 2013;68:1289-1297.

227. Bachert C, van Steen K, Zhang N, Holtappels G, Cattaert T, Maus B et al. Specific IgE against Staphylococcus aureus enterotoxins: an independent risk factor for asthma. $J$ Allergy Clin Immunol 2012;130:376-381.

228. Finkelman FD. Diesel exhaust particle exposure during pregnancy promotes development of asthma and atopy. $J$ Allergy Clin Immunol 2014;134:73-74.

229. Karvonen AM, Hyvarinen A, Rintala H, Korppi M, Taubel M, Doekes G et al. Quantity and diversity of environmental 
microbial exposure and development of asthma: a birth cohort study. Allergy 2014;69:1092-1101.

230. Bisgaard H, Bonnelykke K, Stokholm J. Immune-mediated diseases and microbial exposure in early life. Clin Exp Allergy 2014;44:475-481.

231. Fyhrquist N, Ruokolainen L, Suomalainen A, Lehtimaki S, Veckman V, Vendelin J et al. Acinetobacter species in the skin microbiota protect against allergic sensitization and inflammation. J Allergy Clin Immunol 2014;134:1301-1309.

232. Legatzki A, Rosler B, von Mutius E. Microbiome diversity and asthma and allergy risk. Curr Allergy Asthma Rep 2014;14:466.

233. Huang YJ, Boushey HA. The microbiome in asthma. J Allergy Clin Immunol 2015;135:25-30.

234. Abrahamsson TR, Wu RY, Jenmalm MC. Gut microbiota and allergy: the importance of the pregnancy period. Pediatr Res 2015;77:214-219.

235. Abrahamsson TR, Sandberg Abelius M, Forsberg A, Bjorksten B, Jenmalm MC. A Th1/Th2-associated chemokine imbalance during infancy in children developing eczema, wheeze and sensitization. Clin Exp Allergy 2011;41:1729-1739.

236. Bjorksten F, Suoniemi I, Koski V. Neonatal birch-pollen contact and subsequent allergy to birch pollen. Clin Allergy 1980;10:585-591.

237. Graf N, Johansen P, Schindler C, Wuthrich B, Ackermann-Liebrich U, Gassner M et al. Analysis of the relationship between pollinosis and date of birth in Switzerland. Int Arch Allergy Immunol 2007;143:269275.

238. Kihlstrom A, Lilja G, Pershagen G, Hedlin G. Exposure to birch pollen in infancy and development of atopic disease in childhood. J Allergy Clin Immunol 2002; 110:78-84.

239. Eriksson NE, Holmen A. Skin prick tests with standardized extracts of inhalant allergens in 7099 adult patients with asthma or rhinitis: cross-sensitizations and relationships to age, sex, month of birth and year of testing. J Investig Allergol Clin Immunol 1996;6:36-46.
240. Aalberse RC, Nieuwenhuys EJ, Hey M, Stapel SO. 'Horoscope effect' not only for seasonal but also for non-seasonal allergens. Clin Exp Allergy 1992;22:10031006.

241. Schafer T, Przybilla B, Ring J, Kunz B, Greif A, Uberla K. Manifestation of atopy is not related to patient's month of birth. Allergy 1993;48:291-294.

242. Kihlstrom A, Lilja G, Pershagen G, Hedlin G. Exposure to high doses of birch pollen during pregnancy, and risk of sensitization and atopic disease in the child. Allergy 2003;58:871-877.

243. Hateboer G, Gennissen A, Ramos YF, Kerkhoven RM, Sonntag-Buck V, Stunnenberg $\mathrm{HG}$ et al. BS69, a novel adenovirus E1A-associated protein that inhibits E1A transactivation. EMBO $J$ 1995;14:31593169.

244. Haahtela T, von Hertzen L, Makela M, Hannuksela M. Finnish Allergy Programme 2008-2018-time to act and change the course. Allergy 2008;63:634-645. 